\title{
Dünyada ve Türkiye'de Toplam Vergi Yükü ve Ekonomik Büyüme Üzerindeki Etkileri
}

\author{
Total Tax Burden in the World and Turkey and Its Impact on Economic \\ Growth
}

Öz

Kurum ve bireylerin tasarruf ve harcama kararları üzerinde belirleyici olan en önemli iki unsur gelir ile vergi oranlarıdır. Vergi yükü olgusu ülke gelişmişlik göstergelerinden biri olmakla beraber kamu ekonomisinin milli ekonomi içerisindeki payın göstermesi açısından da önem taşımaktadır. Yüksek vergi yükü kullanılabilir gelirde meydana getirdiği olumsuz etkiler nedeniyle tasarruf oranlarm azalttığından bir ülke ekonomisinde vergi yükünün ekonomik faaliyetleri negatif yönde etkileyecek seviyede olmaması gerekmektedir. Vergilerin farkl birçok ekonomik gösterge üzerinde etkili olması vergi politikalarının da etkin bir biçimde uygulanması gerektiğini göstermektedir. Adil bir vergi sisteminde, ödenecek olan vergilerin vergiyi ödeyen bireyin ödeme gücüne uygun bir nitelikte olması gerektiğinden vergi yükünü oluşturan dolayl ve dolaysız vergi oranlarmın birbirine yakın düzeyde olmast gerekmektedir.

Çalışmanın amacını, Türkiye'deki ve dünya genelindeki diğer ülkelerdeki vergilerin ve vergi yüklerinin niteliklerini ve düzeylerini ortaya koymak, Türkiye'de mevcut olan toplam vergi yükünü OECD ülkeleri ve seçilmiş ülkelerin toplam vergi yükleriyle karşılaştırmak, vergilerin ve vergi yükünün ekonomik büyüme üzerinde meydana getirdiğg etkileri değerlendirmek oluşturmaktadır.

\author{
Emek Aslı Cinel \\ Dr. Öğr. Üyesi, Giresun Üniversitesi, \\ İktisadi ve İdari Bilimler Fakültesi, İktisat \\ Bölümü, emekasli@yahoo.com, \\ Orcid:0000-0002-4201-2427
}

\section{Article Type / Makale Türü}

Araştırma Makalesi

Anahtar Kelimeler

Vergi Yükü, Ekonomik Büyüme, Türkiye.

Keywords

Tax Burden, Economic Growth, Turkey.

JEL Codes: E60,E62,E63

Submitted: $\quad 09$ / 04 / 2021

Accepted: $19 / 05 / 2021$

\section{Abstract}

The two most crucial factors determining the saving and expenditure decisions of institutions as well as individuals are income and tax rates. Although the tax burden is one of the development indicators of the country, it is also essential in terms of indicating the share of the public economy in the national economy. The tax burden should not be at a level that would adversely affect the economic activities in a country's economy, as the high tax burden reduces the savings rates due to its negative impacts on the disposable income. Being effective on various economic indicators, taxes imply that tax policies should also be implemented effectively. In a fair tax system, as the taxes to be paid must be appropriate for the taxpayer's ability to pay, the indirect and direct tax rates that constitute the tax burden should converge.

Revealing the characteristics and levels of taxes and tax burdens in Turkey as well as other world countries, comparing the total tax burden of Turkey with that of OECD countries as well as selected countries and assessing the impacts of both taxes and tax burden on economic growth constitute the aim of the study.

\section{Giriş}

Toplam vergi yükü, bir ülkede genellikle bir yıllık dönemde ödenen vergilerin ülkenin gayri safi yurtiçi hasılasına oranını göstermekte olup bireylerin toplam gelirlerinden kamuya aktardıkları payı belirtmektedir. Vergi yükü ödenen vergi miktarı olmayıp ödenen vergi miktarıyla vergi ödeme gücü arasındaki bir bağıntıdır. Dolayısıyla vergi yükü objektif ve sübjektif unsurlar içermektedir (Demir, 2013: 7). Vergilerin ülke ekonomisi üzerindeki etkileri oldukça önemlidir. Vergi reformlarında ya da vergi oranlarındaki bir değişim temel ekonomik göstergeleri de etkilemektedir. Verginin amacı mali amaçla sınırlı değildir, vergi bu amaç haricinde; gelirin yeniden dağılımı, ekonomik istikrarın oluşması, tasarruf ve yatırımlara dönük politikaların yürürlüğe girmesi kanalıyla ekonomik büyümenin sağlanması gibi amaçlara yönelik olarak da kullanılabilmektedir. Bireylerin ödeme gücüne göre vergi alınması adil bir vergi sisteminin var olmasının ön koşuludur. Ödeme gücü aynı olan bireylerin aynı vergi yüküne sahip olması, ödeme gücü farklı olan bireylerin de farklı vergi yüküne sahip olması gerekmektedir (Inaltong, 2012: 16). 
Vergi yükü ve ekonomik büyüme ilişkisi genel olarak incelendiğinde vergi yükündeki artışın, kısa dönemde tasarruf oranını azaltarak uzun dönemde büyümeyi engellediği görülmektedir. Kısa dönemde düşük vergi yükü, uzun dönemde vergi gelirinde yükselme meydana getirmektedir. Vergi yükünün yükselmesi, tasarruf oranının, ekonomik büyümenin ve gelecek dönemdeki potansiyel vergi gelirinin düşmesine neden olmaktadır (Akalın, 2001: 156). Vergi politikalarının uygulanmasıyla yatırım, üretim, tüketim ve tasarruf teşvik edilmekte veya engellenmektedir. Bu şekilde ekonomik istikrarın gerçekleştirilmesi ve atıl kapasite kullanımının teşvik edilmesi mümkün olmaktadır (Edizdoğan ve diğerleri, 2013: 147).

Küreselleşme sonrası süreçte dünya bir tek ortak pazar olmuş, uluslararası mal ve sermaye hareketleri genişlemiştir. Vergi rekabetinin asıl sebebi mal ve sermaye hareketlerinden daha çok pay alma arzusu olarak görülmektedir (Öz ve Yaraşır, 2009: 14). Ekonomiyi olumsuz yönde etkileyen yararlı olmayan vergi rekabeti uygulamaları, uluslararası yatırımları etkileyerek, kaynak dağılımında verimsizliğe, ciddi oranda vergi kayıplarına ve vergi yükünün sermayeden işgücüne doğru kaymasına yol açmakta, ülke refah seviyesini azaltmaktadır (Giray, 2005: 110). Vergilemede yeni arayışların başlaması sonucunda vergiler ülkeler arasında bir rekabet aracı olmakta, yabancı sermaye girişini sağlamak amacıyla ülkeler vergi oranlarında, vergi tarifelerinde ve vergi yüklerinde değişiklikler yapmakta, ülke vergi yapıları köklü bir değişim sürecine girmektedir.

Vergilerin ülke ekonomisi içerisinde eşit ve dengeli dağılımında dolaylı ve dolaysız vergilerin toplanan vergiler içerisindeki oranı önem kazanmaktadır. Dolaysız vergiler ile asgari geçim indirimi, artan oranlı vergi tarifeleri, indirim, istisna ve muafiyet şeklindeki uygulamalarla vergi ödeme gücü arasında ilişki kurulması mümkün olduğu için vergi eşitliği hususunda daha adil sonuçlar vermektedir. Dolaylı vergiler uygulandığı mal ve hizmetler bakımından gelir düzeyi düşük olan kesimin bütçesini daha yüksek oranda etkilediğinden vergi yükünün bu kesim üzerinde yoğunlaşmasına yol açmaktadır (Susam ve Oktayer, 2007: 106). Dolaylı vergiler gelirin kazanılmasını değil harcanmasını temel aldığından daha fazla kazanan yerine daha fazla tüketen kesimi vergilendirmektedir. Bu bağlamda nispi olarak gelir düzeyi daha düşük olan kesimden daha fazla vergi alınmasına neden olduğu için adaletsiz bir sonuç yaratmaktadır. Oysa dolaysız vergiler mükellefin sahip olduğu gelir ya da sermayesinden, sahip olduğu vergi bilinci ya da vergi ahlakı düzeyine göre vergi ödemesine dayalı olduğundan daha adil bir yapıdadır (Yeşilyurt, 2016: 28). Birçok gelişmekte olan ülkeyle benzer biçimde Türkiye'de de vergi yükü dağılımında dolaysız vergilerin vergi gelirleri içerisindeki payının dolaylı vergilere oranla düşük olması vergi dağılımında adaletsizliği de beraberinde getirmektedir. Gelişmiş ülkeler belirli bir gelir seviyesine sahip olduğundan, toplam vergiler içerisinde dolaysız vergilerin oranı yüksek olmakta ve vergi yükü adaletli bir şekilde dağılmaktadır. Dolayısıyla ekonomik büyümenin artırılması amacıyla dolaysız vergilerin vergi gelirleri içindeki payının artırılması gerekmektedir.

Çalışmanın amacını, Türkiye'deki ve dünya genelindeki diğer ülkelerdeki vergilerin ve vergi yüklerinin niteliklerini ve düzeylerini ortaya koymak, Türkiye' de mevcut olan toplam vergi yükünü OECD ülkeleri ve seçilmiş ülkelerin toplam vergi yükleriyle karşılaştırmak, vergilerin ve vergi yükünün ekonomik büyüme üzerinde meydana getirdiği etkileri değerlendirmek oluşturmaktadır. $\mathrm{Bu}$ amaçla OECD, Cumhurbaşkanlığı Strateji ve Bütçe Başkanlığı, TÜİK ve Gelir İdaresi Başkanlığı'nın resmi istatistik verilerinden yararlanılmıştır. Türkiye' deki vergi sisteminin yapısına ve 2002-2020 döneminde Türkiye' deki dolaylı ve dolaysız vergi oranlarına vurgu yapılmıştır. Aynı zamanda çalışmada vergiler ve vergi yükünün ekonomik büyüme üzerindeki etkilerine ilişkin literatür taraması yapılmış, vergi yükünün yaratmış olduğu ekonomik etkilere de değinilmiştir.

\section{Vergiler ve Vergi Yükünün Ekonomik Büyüme Üzerindeki Etkilerine İlişkin Literatür Taramas1}

Literatürde vergilerin ve vergi yükünün ekonomik büyüme üzerindeki etkilerine ilişkin olarak yapılmış farklı çok sayıda çalışma mevcut olup aşağıda bunların bir kısmına tarihsel sıralamayla değinilmiştir. Araştırmaların genelinde vergi oranındaki artışın ekonomik büyümeyi olumsuz yönde etkilediği, dolaylı vergilerdeki azalmanın ekonomik büyümeyi olumlu yönde etkilediği tespit edilmiştir. 
Marsden (1984), yüksek ve düşük gelir düzeyine sahip olan 20 ülke için 1970-1979 dönemini ele aldığı çalışmasında regresyon analizinden yararlanarak vergi gelirleriyle ekonomik büyüme arasındaki ilişkiyi incelemiştir. Buna göre, vergi gelirleriyle GSYH arasındaki oranda \%1 seviyesindeki yükseliş ekonomik büyümeyi \%0,36 seviyesinde düşürmektedir.

Engen ve Skinner (1992) çalışmalarında, gelişmiş ve gelişmekte olan 107 ülke için vergi oranıla ekonomik büyüme arasındaki ilişkiyi yatay kesit analizinden faydalanarak araştırmışlardır. Çalışma sonucunda vergi oranındaki yükselişin ekonomik büyümeyi olumsuz bir şekilde etkilediği belirtilmiştir.

Easterly ve Rebelo (1993) çalışmalarında, 1970-1988 dönemi için 100 farklı ülkeyi, 1870-1988 dönemi için de 125 farklı ülkeyi ele alarak yatay kesit analizi yöntemiyle vergi oranlarıyla ekonomik büyüme arasındaki ilişkiyi incelemişlerdir. Marjinal vergi düzeyindeki yükselişin ekonomik büyümeyle özel sektör yatırımlarının GSYH içerisindeki oranını azalttığını tespit etmişlerdir.

Widmalm (2001), 23 OECD üyesi ülke için 1965-1990 dönemini ele alarak yatay kesit analizi yöntemiyle gelir vergisi oranları ile ekonomik büyüme arasındaki ilişkiyi araştırmıştır. Çalışmanın sonucunda gelir vergisindeki yükselmeyle ekonomik büyüme arasında negatif ilişki olduğunu belirtmiştir.

Koch ve diğerleri (2005), 1960-2002 dönemi için Güney Afrika'da vergi yükü ile ekonomik büyüme arasındaki ilişkiyi araştırmışlardır. Regresyon analizinden yararlanılan çalışmada vergi yükündeki düşüşün ekonomik büyümeyi artırdığını, dolaylı vergilerdeki düşüşün ekonomik büyümeyi yükselttiğini ifade etmişlerdir.

Lee ve Gordon (2005) çalışmalarında, 70 farklı ülke ekonomisinde 1970-1977 dönemine ait kurumlar vergisi ile ekonomik büyüme arasındaki ilişkiyi yatay kesit ve panel veri analiziyle araştırmışlardır. Kurumlar vergisinde meydana gelecek olan \%10 seviyesindeki düşüşün ekonomik büyümeyi ortalama \%1,1 oranında yükselteceğini tespit etmişlerdir.

Tosun ve Abizadeh (2005), OECD ülkelerine yönelik olarak 1980-1999 dönemi için yaptıkları çalışmalarında gelir ve servet vergileriyle, istihdam vergileriyle mal ve hizmetlerden alınan vergilerin ekonomik büyüme üzerindeki etkilerini panel veri analiziyle incelemişlerdir. Gelir ve servet vergilerinin ekonomik büyümeyi olumlu yönde etkilerken istihdam vergileriyle mal ve hizmetlerden alınan vergilerin ekonomik büyüme üzerinde negatif yönde etki yarattığını belirtmişlerdir.

De Wet ve diğerleri (2005) çalışmalarında, 1969-2003 döneminde Güney Afrika'da dolaysız vergilerle ekonomik büyüme arasındaki ilişkiyi regresyon analizini kullanarak incelemişlerdir. Çalışma sonuçlarına göre, dolaysız vergilerdeki düşüş ekonomik büyümeyi artırmaktadır.

Anastassiou ve Dritsaki (2005) çalışmalarında, Yunanistan ekonomisi için 1965-2002 döneminde vergi gelirleriyle ekonomik büyüme arasındaki ilişkiyi eş bütünleşme analizi ve Granger nedensellik testiyle analiz etmişlerdir. Çalışma sonucunda vergi gelirleri ile marjinal dolaysız vergi oranından ekonomik büyümeye doğru nedensellik ilişkisi tespit etmişlerdir.

Temiz (2008), Türkiye için 1960-2006 dönemini ele aldığ1 çalışmasında eş bütünleşme analizi, hata düzeltme yöntemi ve Granger nedensellik testinden faydalanarak vergi gelirleriyle ekonomik büyüme arasındaki ilişkiyi araştırmıştır. Dolaysız vergi gelirleriyle reel gayri safi milli hâsıla arasında pozitif, dolaylı vergi gelirleriyle reel gayri safi yurtiçi hasıla arasında negatif bir ilişkinin varlığını belirtmiştir. Nedensellik testi sonuçlarına göre dolaylı vergi gelirleriyle reel gayri safi milli hâsıla oranı arasında bir ilişki olmadığı, dolaysız vergi gelirleriyle reel gayri safi milli hasıla arasında çift yönlü nedensellik ilişkisi olduğu ifade edilmiştir.

Mucuk ve Alptekin (2008) çalışmalarında, Türkiye ekonomisinde dolaylı ve dolaysız vergilerle ekonomik büyüme arasındaki ilişkiyi 1975-2006 dönemi için araştırmışlardır. Eş bütünleşme analiziyle, Granger nedensellik testi ve VAR analizinin kullanıldığı çalışmada dolaysız ve dolaylı vergilerin ekonomik büyüme oranı ile pozitif ilişki içerisinde oldukları, dolaysız vergilerden ekonomik büyümeye doğru tek yönlü bir nedensellik ilişkisinin varlığı belirtilmiştir.

Arnold (2008), 21 OECD ülkesi üzerinde yaptığ1 çalışmasında panel veri analizinden faydalanmış ve vergi oranı ile ekonomik büyüme arasındaki ilişkiyi araştırmıştır. Gelir vergisinin 
tüketimle servetten alınan vergilere oranla daha yüksek düzeyde ekonomik büyüme üzerinde olumsuz etkide bulunduğunu vurgulamıştır.

Padda ve Akram (2009) çalışmalarında, Pakistan, Hindistan ve Sri Lanka ekonomileri için 19732008 döneminde vergi oranlarıyla ekonomik büyüme arasındaki ilişkiyi araştırmışlardır. Regresyon ve VAR analizinin kullanıldığı çalışma sonucunda yüksek vergi oranlarının ekonomik büyümeyi olumsuz yönde etkilediği ifade edilmiştir.

Katırcıoğlu (2010), Türkiye'de 1960-2006 döneminde vergi gelirleriyle reel GSYH arasındaki ilişkiyi eş bütünleşme analiziyle araştırmış olup reel GSYH ile toplam vergi gelirleri arasında herhangi bir ilişki olmadığını öne sürmüştür.

Arısoy ve Ünlükaplan (2010) çalışmalarında, Türkiye' de dolaylı ve dolaysız vergilerle ekonomik büyüme oranı arasındaki ilişkiyi 1968-2006 dönemi için regresyon analizi ile incelemişler, dolaylı vergilerle ekonomik büyüme arasında pozitif yönlü bir ilişki olduğunu, dolaysız vergilerle ekonomik büyüme arasındaysa ilişki olmadığını tespit etmişlerdir.

Ardıç ve diğerleri (2010), 2003 yılına ait verilerden yararlanarak Türkiye ekonomisi için dolaylı vergilerle ekonomik büyüme arasındaki ilişkiyi araştırmışlardır. Çalışmanın sonucunda dolaylı vergi oranındaki yükselmenin özellikle düşük gelir seviyesine sahip olan kesim üzerindeki vergi yükünü yükselttiğini savunmuşlardır.

Göçer ve diğerleri (2010) çalışmalarında, Türkiye'de 1924-2009 döneminde sınır testi eş bütünleşme yaklaşımıyla dolaylı ve dolaysız vergilerle ekonomik büyüme arasındaki ilişkiyi incelemişler ve dolaylı ve dolaysız vergilerle ekonomik büyüme seviyesi arasında uzun dönemde pozitif yönlü ilişkinin olduğunu ifade etmişlerdir. Dolaysız vergilerin etkisinin dolaylı vergilerden daha yüksek olduğunu, kısa dönemde dolaysız ve dolaylı vergilerin ekonomik büyümeyi pozitif yönde etkilediğini ifade etmişlerdir.

Veronika ve Lenka (2012) çalışmalarında, 27 Avrupa Birliği ülkesi için panel veri analizinden yararlanarak kurumlar vergisiyle ekonomik büyüme oranı arasındaki ilişkiyi araştırmışlardır. Çalışma sonucunda Avrupa Birliği ülkelerinden 15 tanesinde kurumlar vergisindeki yükselmenin ekonomik büyümeyi düşürdüğü sonucuna varılmıştır.

Mangır ve Ertuğrul (2012), Türkiye' de 1988-2011 döneminde vergi yükü ile ekonomik büyüme arasındaki ilişkiyi Pesaran (2001) tarafından ortaya konulan sınır testi eş bütünleşme analiziyle ve ARDL yöntemiyle incelemişlerdir. Çalışma sonucunda vergi yüküyle GSYH arasında eş bütünleşme bulunmuş, ARDL yöntemi sonuçlarına göre ise uzun ve kısa dönemde vergi yüküyle GSYH arasında istatistiksel olarak negatif ilişki tespit edilmiştir.

Erdoğan ve diğerleri (2013) çalışmalarında, Türkiye için 1998:1-2011:4 döneminde dolaylı ve dolaysız vergilerle ekonomik büyüme oranı arasındaki ilişkiyi eş bütünleşme analizi, hata düzeltme yöntemi ve Granger nedensellik testiyle araştırmışlardır. Kısa dönemde dolaysız vergilerin, uzun dönemde ise dolaylı vergilerin ekonomik büyüme üzerinde etkili olduğunu belirtmişlerdir.

Canavire-Bacarreza ve diğerleri (2013) çalışmalarında, 14 Latin Amerika ülkesi ile 81 gelişmiş ve gelişmekte olan ülke ekonomisini 1990-2009 dönemi için ele almışlar, bu ülkelerde vergi oranlarıyla ekonomik büyüme oranı arasındaki ilişkiyi VAR yöntemi ve panel veri analiziyle incelemişlerdir. Latin Amerika ülkelerinin büyük bir kısmında ekonomik büyümeyle gelir vergisi arasında negatif yönlü bir ilişki olmadığını, tüketim vergisiyle ekonomik büyüme arasında pozitif yönlü bir ilişkinin olduğunu tespit etmişlerdir. 81 ülkede gelir vergisiyle ekonomik büyüme arasında negatif ilişki olduğunu, tüketim vergileriyle ekonomik büyüme arasında pozitif yönlü ilişkinin varlığını savunmuşlardır.

Saraç (2015) çalışmasında, 1969-2013 döneminde Türkiye' de vergi yüküyle ekonomik büyüme oranı arasındaki ilişkiyi Markov rejim değişim tekniğiyle araştırmıştır. Çalışma sonuçlarına göre dolaysız vergilerin GSYH içerisindeki oranı arttıkça ekonomik büyüme azalmakta, dolaylı vergilerin GSYH içerisindeki oranı arttıkça ekonomik büyüme artmaktadır.

Karayılmazlar ve Göde (2017) çalışmalarında, 1965-2015 döneminde Türkiye ekonomisinde vergi yüküyle ekonomik büyüme arasındaki ilişkiyi VECM analiziyle araştırmışlardır. Çalışma sonucunda vergi yükündeki pozitif yönlü değişimlerin ekonomik büyümeyi negatif yönde 
etkilemesine rağmen Türkiye ekonomisi bakımından bu sonucun istatistiki olarak anlamsız olduğunu ifade etmişlerdir.

Organ ve Ergen (2017), 1980-2015 döneminde Türkiye' de vergi yükü ile ekonomik büyüme arasındaki ilişkiyi Pesaran ve diğerleri (2001) tarafından önerilen sınır testiyle analiz etmişlerdir. Çalışmanın sonucunda vergi yüküyle ekonomik büyümenin eş-bütünleşme ilişkisine sahip olup, iki değişken arasında uzun dönemde negatif bir ilişkinin mevcut olduğu belirtilmiştir.

Çelikay (2018) çalışmasında, 2005-2014 döneminde vergi yüküyle ekonomik büyüme arasındaki ilişkiyi Türkiye'de 81 il örnekleminde incelemiştir. Çalışma sonucunda illere göre vergi yüküyle illerin ekonomik büyüme oranları arasında uzun dönemli eş bütünleşik bir ilişki tespit edilmiş olup vergi yükünde oluşacak olan \%1'lik yükselmenin ekonomik büyüme hızını kısa dönemde \%0,6 oranında azaltacağı, uzun dönemde ise \% 0,9 oranında artıracağı belirtilmiştir.

Koç (2019), Türkiye'de 1980-2017 döneminde vergi yükünün ekonomik büyüme üzerindeki etkilerini araştırdığı çalışmasında Johansen eş bütünleşme analiziyle hata düzeltme modelinden (VEC) yararlanmıştır. Çalışma sonucunda vergi yüküyle ekonomik büyüme arasında istatistiki olarak anlamlı ve pozitif yönde bir ilişkinin olduğu sonucuna varılmıştır.

Boğa (2020) çalışmasında, Türkiye' de 1965-2018 döneminde farklı vergi türlerinin ekonomik büyüme üzerindeki etkisini doğrusal olmayan ARDL (NARDL) eş bütünleşme yaklaşımıyla analiz etmiştir. Çalışma sonucunda elde edilen bulgular değişkenler arasında uzun dönemli senkronize bir ilişkinin varlığını göstermekte olup vergi gelirlerinin ekonomik büyüme üzerindeki pozitif etkisi vergi indirimlerinin meydana getirdiği pozitif etkiden daha güçlüdür.

Özpençe ve Mercan (2020) çalışmalarında, Türkiye'de 1970-2018 döneminde vergi yüküyle ekonomik büyüme arasındaki ilişkiyi VAR analizi ve Granger nedensellik testiyle analiz etmişlerdir. Çalışma sonucuna göre vergi yüküyle ekonomik büyüme oranı arasında negatif yönde bir ilişki söz konusudur.

Kutbay (2021), doğrudan ve dolaylı vergilerle vergi yükünün ekonomik büyüme üzerindeki etkilerini, 30 OECD ülkesi için 2000-2017 dönemi kapsamında panel veri analizinden yararlanarak analiz etmiştir. Çalışma sonucunda doğrudan vergi gelirlerindeki artışın ekonomik büyüme üzerinde istatistiksel olarak anlamlı ve pozitif etkiye sahip olduğu, dolaylı vergi gelirlerinin ve vergi yükünün ise ekonomik büyüme üzerinde pozitif ancak istatistiksel olarak anlamsız etkilerinin olduğu ifade edilmiştir.

\section{Türkiye'de Vergi Yükü}

Türkiye' deki vergilendirmenin yapısı dikkate alındığında, vergilendirmenin ekonomik etki ve sonuçları değerlendirildiğinde, vergi yükünün adil bir biçimde dağıtılmasının ekonominin büyümesi, tasarruf ve yatırım oranlarının artması, etkin kaynak dağılımının sağlanması açısından etkilerinin oldukça yüksek olduğu görülmektedir. Yoksulluğun azaltılması ve gelir dağılımı adaletsizliğinin sona erdirilmesinde vergilendirmenin önemi büyüktür. Gelir düzeyi farklı olan kesimlere uygulanan vergilerin ve vergi oranlarının farklı olması, kamu harcamalarından yararlanma hususunda farklı gelir düzeyine sahip olan kesimlere öncelik tanınması gibi politikalar adaletsizliği azaltmaya yöneliktir (Ay ve Haydanlı, 2017: 145).

Vergi yükünün sosyal ve ekonomik yapı üzerindeki etkisi toplam vergi yükünün değerlendirilmesini gerektirmektedir. Aşağıda yer alan tablo Türkiye'deki vergi yükünün 2004-2020 dönemindeki gelişimini göstermektedir.

Tablo 1. Türkiye'de Toplam Vergi Yükü

\begin{tabular}{|c|c|c|c|c|c|c|c|c|c|c|}
\hline Yillar & $\begin{array}{c}\text { (1)Kon. } \\
\text { Bütçe } \\
\text { (Milyon } \\
\text { TL) }\end{array}$ & $\begin{array}{c}\text { (2)Mah. } \\
\text { İdareler } \\
\text { (Milyon } \\
\text { TL) }\end{array}$ & $\begin{array}{l}\text { (3) } \\
\text { Fonlar } \\
\text { (Mily } \\
\text { on TL) }\end{array}$ & $\begin{array}{l}\text { (4)Top. } \\
(1+2+3)\end{array}$ & $\begin{array}{l}\text { (5)Sosya } \\
1 \text { Güv. } \\
\text { Kurum } \\
\text { (Milyon } \\
\text { TL) }\end{array}$ & $\begin{array}{c}\text { (6)Top. } \\
(4+5)\end{array}$ & $\begin{array}{c}\text { (7)Vergi } \\
\text { İade } \\
\text { (Asgari } \\
\text { Geçim } \\
\text { İndirimi } \\
\text { Dahil) }\end{array}$ & $\begin{array}{c}\text { (8)GSYH } \\
\text { (Piyasa } \\
\text { Fiyatlari, } \\
\text { Milyon } \\
\text { TL) }\end{array}$ & $\begin{array}{c}\text { Vergi } \\
\text { yükü } \\
\text { (Sosyal } \\
\text { Güv. } \\
\text { Kurum } \\
\text { gelirler } \\
\text { hariç, \%) }\end{array}$ & $\begin{array}{c}\text { Vergi } \\
\text { yüküi } \\
\text { (Sosyal } \\
\text { Güv. } \\
\text { Kurum } \\
\text { gelirler } \\
\text { dahil, \%) }\end{array}$ \\
\hline 2005 & 133.309 & 2.715 & 0 & 136.024 & 33.104 & 169.128 & 13.615 & 648.932 & 18,2 & 23,1 \\
\hline 2006 & 151.351 & 3.464 & 0 & 154.815 & 43.742 & 198.557 & 13.791 & 758.391 & 17,9 & 23,4 \\
\hline
\end{tabular}




\begin{tabular}{|c|c|c|c|c|c|c|c|c|c|c|}
\hline 2007 & 171.213 & 3.910 & 0 & 175.123 & 47.505 & 222.627 & 18.229 & 843.178 & 17,8 & 23,2 \\
\hline 2008 & 184.966 & 4.346 & 0 & 189.312 & 58.718 & 248.031 & 16.691 & 950.534 & 17,4 & 23,3 \\
\hline 2009 & 190.160 & 3.899 & 0 & 194.059 & 58.720 & 252.779 & 17.523 & 952.559 & 17,7 & 23,5 \\
\hline 2010 & 228.527 & 6.095 & 0 & 234.623 & 71.696 & 306.618 & 17.738 & 1.098 .799 & 18,7 & 24,9 \\
\hline 2011 & 275.933 & 7.127 & 0 & 283.060 & 94.303 & 377.363 & 21.889 & 1.297 .713 & 18,7 & 25,5 \\
\hline 2012 & 306.638 & 7.485 & 0 & 314.123 & 102.004 & 416.127 & 27.564 & 1.416 .798 & 18,3 & 24,8 \\
\hline 2013 & 355.992 & 8.481 & 0 & 364.473 & 118.588 & 483.061 & 29.500 & 1.567 .289 & 18,5 & 25,1 \\
\hline 2014 & 387.441 & 9.754 & 0 & 397.195 & 137.462 & 534.657 & 34.558 & 1.748 .169 & 17,7 & 24,5 \\
\hline 2015 & 448.396 & 11.237 & 0 & 459.633 & 163.108 & 622.741 & 40.154 & 2.338 .647 & 17,9 & 24,9 \\
\hline 2016 & 506.227 & 12.685 & 0 & 518.913 & 189.476 & 708.389 & 46.742 & 2.608 .526 & 18,1 & 25,4 \\
\hline 2017 & 598.668 & 13.751 & 0 & 612.419 & 214.028 & 826.447 & 61.545 & 3.104 .907 & 17,7 & 24,6 \\
\hline 2018 & 713.554 & 17.381 & 0 & 730.935 & 260.927 & 991.863 & 82.467 & 3.740 .519 & 17,3 & 24,3 \\
\hline 2019 & 856.538 & 21.388 & 0 & 877.926 & 297.331 & 1.175 .257 & 99.376 & 4.450 .278 & 17,5 & 24,2 \\
\hline 2020 & 1.000 .908 & 26.039 & 0 & 1.062 .947 & 343.784 & 1.370 .731 & 113.089 & 5.149 .551 & 17,7 & 24,4 \\
\hline
\end{tabular}

Kaynak: Cumhurbaşkanlığı Strateji ve Bütçe Başkanlığı

Tablo 1'de Türkiye' de 2005-2020 dönemine ait toplam vergi yükü yer almaktadır. Tabloda yer alan konsolide bütçe verileri 2006 yılından itibaren merkezi yönetim bütçesi olmuştur. 2005-2020 döneminde Türkiye'de toplam vergi yükünün yıllara bağlı olarak artış eğiliminde olduğu görülmektedir. 2005 yılında sosyal güvenlik kurumu gelirler dâhil toplam vergi yükü \%23,1 iken 2010 yılında \%24,9, 2015 yılında \%24,9 ve 2020 yılında \% 24,4 seviyesine ulaşmıştır. Türkiye'de vergi yükünün 2005-2020 döneminde artmasının nedenleri arasında ücret ve harcamaların vergi yükünde ortalamanın üstünde olması, bireysel vergi yükü, kurumlar üzerinden alınan vergilerin yükü ve servet vergisi yükünde ortalamanın altında olması gösterilebilir. Ayrıca mal ve hizmet vergi yüklerinin yüksekliği, bireysel vergi yüküyle kurumlar üzerinden alınan vergi yükünün düşük olması bu durumu daha da kötüleştirmektedir (Kılıçaslan ve Yavan, 2017).

\section{Türkiye'de Asgari Ücret Üzerindeki Vergi Yükü}

Vergi yükünün yükümlüler arasında gelir düzeylerine göre ve eşit bir şekilde dağıtılıp dağıtılmadığı hususunda asgari ücret üzerindeki vergi yükü önem kazanmaktadır. Türkiye'de asgari ücret düzeyi tanımlanırken ailenin geçimini sağlayacak bir tutardan çok işçinin gereksinimlerini göz önünde bulunduran bir uygulama söz konusudur. Ayrica asgari ücret üzerinden vergi ve benzeri kesintiler de yapılmaktadır. Kesintiler işçinin net gelirini azaltmakta, işverenin mali sorumluluklarını artırmakta ve kayıt dışılığa yönelime yol açmaktadır (Korkmaz, 2001).

Tablo 2. Türkiye'de Asgari Ücret Üzerindeki Yükler (Yıllık)

\begin{tabular}{|c|c|c|c|c|c|c|c|c|c|c|}
\hline & 2002 & 2011 & 2012 & 2013 & 2014 & 2015 & 2016 & 2017 & 2018 & 2019 \\
\hline Brüt Asgari Ücret & 2.837 & 9.801 & 10.962 & 12.001 & 13.230 & 14.850 & 19.764 & 21.330 & 24.354 & 30.701 \\
\hline SSK Primi İşçi Hissesi (\%14) & 397 & 1.372 & 1.535 & 1.680 & 1.852 & 2.079 & 2.767 & 2.986 & 3.410 & 4.298 \\
\hline İşsizlik Sigortası Primi İşçi Hissesi (\%1) & 28 & 98 & 110 & 120 & 132 & 149 & 198 & 213 & 244 & 307 \\
\hline Gelir Vergisi Matrahı & 2.052 & 8.331 & 9.318 & 10.201 & 11.246 & 12.622 & 16.799 & 18.130 & 20.701 & 26.096 \\
\hline Gelir Vergisi & 308 & 1.250 & 1.398 & 1.530 & 1.699 & 1.924 & 2.730 & 2.976 & 3.400 & 4.319 \\
\hline Damga Vergisi $(\% 0,759)$ & 17 & 65 & 72 & 91 & 100 & 113 & 150 & 162 & 185 & 233 \\
\hline Toplam Vergi & 325 & 1.314 & 1.470 & 1.621 & 1.800 & 2.037 & 2.880 & 3.138 & 3.585 & 4.552 \\
\hline İşçiden Yapılan Toplam Kesinti & 750 & 2.784 & 3.114 & 3.421 & 3.784 & 4.265 & 5.844 & 6.338 & 7.238 & 9.157 \\
\hline \multicolumn{11}{|l|}{ Asgari Geçim İndirimi ve Desteği } \\
\hline (Bekar-çocuksuz) & - & 717 & 798 & 881 & 964 & 1.081 & 1.692 & 1.600 & 1.827 & 2.303 \\
\hline (Evli-iki çocuklu) & - & 1.075 & 1.197 & 1.321 & 1.446 & 1.622 & 2.248 & 2.400 & 2.740 & 3.454 \\
\hline (Evli-dört çocuklu) & - & 1.147 & 1.277 & 1.409 & 1.542 & 1.838 & 2.520 & 2.720 & 3.105 & 3.914 \\
\hline \multicolumn{11}{|l|}{ Net Ücret } \\
\hline (Bekar-çocuksuz) & 2.087 & 7.733 & 8.646 & 9.460 & 10.410 & 11.667 & 15.612 & 16.592 & 18.942 & 23.846 \\
\hline (Evli-iki çocuklu) & 2.087 & 8.092 & 9.044 & 9.900 & 10.892 & 12.207 & 16.168 & 17.392 & 19.856 & 24.997 \\
\hline (Evli-dört çocuklu) & 2.087 & 8.163 & 9.124 & 9.989 & 10.988 & 12.423 & 16.439 & 17.712 & 20.221 & 25.458 \\
\hline SSK Primi işveren hissesi & 553 & 1.421 & 1.589 & 1.740 & 2.051 & 2.302 & 3.063 & 3.306 & 3.775 & 4.759 \\
\hline İşsizlik Sigortası İşveren Hissesi (\%2) & 57 & 196 & 219 & 240 & 265 & 297 & 395 & 427 & 487 & 614 \\
\hline Devlet Desteği (100 TL, 2016 yılı) & & & & & & & 1.200 & 1.200 & 900 & \\
\hline \multicolumn{11}{|l|}{ Asgari Ücret Üzerindeki Kesintiler } \\
\hline (Bekar-çocuksuz) & 1.360 & 3.685 & 4.125 & 4.521 & 5.135 & 5.782 & 6.411 & 7.271 & 8.774 & 12.227 \\
\hline (Evli-iki çocuklu) & 1.360 & 3.326 & 3.726 & 4.080 & 4.653 & 5.241 & 5.855 & 6.471 & 7.860 & 11.076 \\
\hline (Evli-dört çocuklu) & 1.360 & 3.255 & 3.646 & 3.992 & 4.557 & 5.025 & 5.583 & 6.151 & 7.495 & 10.616 \\
\hline İşverene Maliyet (100 TL Devlet Desteği Dahil) & 3.447 & 11.418 & 12.771 & 13.981 & 15.545 & 17.449 & 22.023 & 23.863 & 27.716 & 36.073 \\
\hline
\end{tabular}


Tablo 2' de Türkiye' de asgari ücret üzerindeki yükler yıllık olarak yer almaktadır. Tablo 2' deki veriler asgari ücret üzerinde birden fazla vergi ve benzeri mali yükümlülükler bulunduğunu, asgari ücret üzerindeki vergi yükünün çok yüksek olduğunu göstermektedir. Mali yükümlülükler asgari ücretin net değerini azaltmakta, kayıt dışı istihdam gibi ekonomik problemleri ortaya çıkarmaktadır. Asgari ücretin vergilendirilmemesine yönelik talepler, devletin ciddi gelir kaybı olacağ1 düşüncesiyle uygulanmamaktadır (Korkmaz, 2001). Asgari ücret üzerindeki vergi yükünün yanı sıra, asgari ücretin işverene maliyeti de önemli bir sorun olmaktadır. Öyle ki, 2002 yılında asgari ücretin işverene yıllık maliyeti (100 TL devlet desteği dâhil) 3.447 TL iken 2019 yılında bu oran 36.073 TL'ye yükselmiştir.

Tablo 3. Türkiye'de Asgari Ücret Üzerindeki Yıllık Yük Oranları (\%)

\begin{tabular}{|c|c|c|c|c|c|c|c|c|c|c|}
\hline & 2002 & 2011 & 2012 & 2013 & 2014 & 2015 & 2016 & 2017 & 2018 & 2019 \\
\hline \multicolumn{11}{|l|}{ Asgari Geçim İndirimi Öncesi } \\
\hline Toplam Yük/Toplam Maliyet & 39,5 & 38,5 & 38,5 & 38,6 & 39,2 & 39,3 & 36,8 & 37,2 & 38,2 & 40,3 \\
\hline Toplam Vergi/Toplam Maliyet & 9,4 & 11,5 & 11,5 & 11,6 & 11,6 & 11,7 & 13,1 & 13,2 & 12,9 & 12,6 \\
\hline Toplam Prim/Toplam Maliyet & 30,0 & 27,0 & 27,0 & 27,0 & 27,7 & 27,7 & 23,7 & 24,0 & 25,3 & 27,7 \\
\hline Toplam Yük/Brüt Ücret & 47,9 & 44,9 & 44,9 & 45,0 & 46,1 & 46,2 & 41,0 & 41,6 & 43,5 & 47,3 \\
\hline Toplam Vergi/Brüt Ücret & 11,4 & 13,4 & 13,4 & 13,5 & 13,6 & 13,7 & 14,6 & 14,7 & 14,7 & 14,8 \\
\hline Toplam Prim/Brüt Ücret & 36,5 & 31,5 & 31,5 & 31,5 & 32,5 & 32,5 & 26,4 & 26,9 & 28,8 & 32,5 \\
\hline \multicolumn{11}{|c|}{ Asgari Geçim İndirimi Sonrası (Bekar Çocuksuz) } \\
\hline Toplam Yük / Toplam Maliyet & 39,5 & 32,4 & 32,3 & 32,3 & 33,0 & 33,1 & 29,1 & 30,5 & 31,7 & 33,9 \\
\hline Toplam Vergi / İşverene Maliyet & 9,4 & 5,4 & 5,3 & 5,3 & 5,4 & 5,5 & 5,4 & 6,4 & 6,3 & 6,2 \\
\hline Toplam Yük / Brüt Ücret & 47,9 & 37,8 & 37,6 & 37,7 & 38,8 & 38,9 & 32,4 & 34,1 & 36,0 & 39,8 \\
\hline Toplam Vergi / Brüt Ücrete Maliyet & 11,4 & 6,3 & 6,1 & 6,2 & 6,3 & 6,4 & 6,0 & 7,2 & 7,2 & 7,3 \\
\hline \multicolumn{11}{|l|}{ (Evli-2 çocuklu) } \\
\hline Toplam Yük / Toplam Maliyet & 39,5 & 29,4 & 29,2 & 29,2 & 29,9 & 30,0 & 26,6 & 27,1 & 28,4 & 30,7 \\
\hline Toplam Vergi / İşverene Maliyet & 9,4 & 2,3 & 2,1 & 2,1 & 2,3 & 2,4 & 2,9 & 3,1 & 3,0 & 3,0 \\
\hline Toplam Yük / Brüt Ücret & 47,9 & 34,2 & 34,0 & 34,0 & 35,2 & 35,3 & 29,6 & 30,3 & 32,3 & 36,1 \\
\hline Toplam Vergi / Brüt Ücrete Maliyet & 11,4 & 2,7 & 2,5 & 2,5 & 2,7 & 2,8 & 3,2 & 3,5 & 3,5 & 3,6 \\
\hline \multicolumn{11}{|l|}{ (Evli-4 çocuklu) } \\
\hline Toplam Yük / Toplam Maliyet & 39,5 & 28,7 & 28,6 & 28,6 & 29,3 & 28,8 & 25,4 & 25,8 & 27,0 & 29,4 \\
\hline Toplam Vergi / İşverene Maliyet & 9,4 & 1,7 & 1,5 & 1,5 & 1,7 & 1,1 & 1,6 & 1,8 & 1,7 & 1,8 \\
\hline Toplam Yük / Brüt Ücret & 47,9 & 33,5 & 33,3 & 33,3 & 34,4 & 33,8 & 28,3 & 28,8 & 30,8 & 34,6 \\
\hline Toplam Vergi / Brüt Ücrete Maliyet & 11,4 & 2,0 & 1,8 & 1,8 & 1,9 & 1,3 & 1,8 & 2,0 & 2,0 & 2,1 \\
\hline
\end{tabular}

Kaynak: Cumhurbaşkanlığ1 Strateji ve Bütçe Başkanlığ 1

Tablo 3'te Türkiye' de 2002-2019 dönemine ait asgari ücret üzerindeki yıllık yük oranları yüzde olarak görülmektedir. Asgari geçim indirimi öncesinde toplam yük/toplam maliyet oran 2002 yılında \%39,5 iken 2019 yılında \%40,3 seviyesine ulaşmıştır. Asgari geçim indirimi sonrası (bekarçocuksuz) 2002 yılında toplam yük/toplam maliyet \%39,5 iken 2019 y1lında bu oran \%33,9'a gerilemiştir. Aynı oran evli-iki çocuklu bir aile için 2019 yılında \%30,7 olarak, evli-dört çocuklu bir aile için ise \%29,4 olarak gerçekleşmiştir.

Türkiye' de asgari ücret düzeyinin açlık ve yoksulluk sınırının altında olması ve vergi yükünün de oldukça yüksek düzeyde seyretmesi düşük gelir grubuna sahip olan kesimin gelirini düşürürken, işçilik maliyetlerini yükseltmektedir. Bu süreç işveren kesimin kayıt dışı istihdama yönelmesinde önemli bir rol üstlenmektedir (Korkmaz, 2004).

\section{Türkiye'de Toplanan Vergi Tutarı ve Vergi Gelirlerinin Dağılımı}

Türkiye' de ekonomik büyümenin artırılıp, gelir dağılımı adaletsizliğinin azaltılması hususunda toplanan vergi tutarı, dolaylı ve dolaysız vergi gelirlerinin toplam vergi gelirleri içindeki payı ve vergi gelirlerinin dağılımı önemli bir rol üstlenmektedir.

Tablo 4. 2002-2020 Döneminde Türkiye'de Toplanan Vergi

\begin{tabular}{|c|c|c|c|c|}
\hline Yillar & $\begin{array}{c}\text { Toplanan Vergi } \\
\text { (Milyar TL) }\end{array}$ & $\begin{array}{c}\text { Y1lık Ortalama (ABD } \\
\text { Dolar/TL) }\end{array}$ & $\begin{array}{c}\text { Toplanan Vergi } \\
\text { (Milyar ABD Dolar) }\end{array}$ & $\begin{array}{c}\text { Dolayli ve Dolaysiz } \\
\text { Vergi Gelirlerinin } \\
\text { Toplam Payı (\%) }\end{array}$ \\
\hline 2002 & 59.6 & 1.51 & 39.5 & 80 \\
\hline 2003 & 84.3 & 1.5 & 56.2 & 86 \\
\hline 2004 & 101 & 1.43 & 70.7 & 84 \\
\hline 2005 & 119.3 & 1.35 & 88.3 & 80 \\
\hline 2006 & 151.3 & 1.44 & 105 & 83 \\
\hline
\end{tabular}




\begin{tabular}{|c|c|c|c|c|}
\hline 2007 & 171.1 & 1.31 & 130.6 & 84 \\
\hline 2008 & 190 & 1.3 & 146.1 & 84 \\
\hline 2009 & 196.3 & 1.55 & 126.7 & 84 \\
\hline 2010 & 235.7 & 1.51 & 156.1 & 87 \\
\hline 2011 & 284.5 & 1.68 & 176.2 & 89 \\
\hline 2012 & 317.2 & 1.8 & 192.4 & 87 \\
\hline 2013 & 367.5 & 1.91 & 183.4 & 88 \\
\hline 2014 & 401.7 & 2.19 & 170.4 & 89 \\
\hline 2015 & 465.2 & 2.73 & 175.4 & 87 \\
\hline 2016 & 529.6 & 3.02 & 171.5 & 89 \\
\hline 2017 & 626.1 & 3.65 & 153.1 & 86 \\
\hline 2018 & 738.2 & 4.82 & 144.3 & 88 \\
\hline 2019 & 819.6 & 5.68 & 140 & \\
\hline 2020 & 983.1 & 7.02 & & 89 \\
\hline
\end{tabular}

Kaynak: Gelir İdaresi Başkanlığı

Tablo 4'te 2002-2020 döneminde Türkiye' de toplanan vergi tutarı ile dolaylı ve dolaysız vergi gelirlerinin toplam payı yer almaktadır. Gelir İdaresi Başkanlığı tarafından açıklanan yıllara göre genel bütçe gelirleri tablosunda vergi gelirleri kalemini incelediğimizde, devletin 2002-2020 döneminde toplamda 6 trilyon 841 milyar TL tutarında vergi geliri elde ettiği görülmektedir. Yıllık ortalama dolar kurlarını göz önüne alarak vergi gelirini dolar bazında hesapladığımızda bu tutar 2 trilyon 595 milyar dolara eşit olmaktadır. Bunun yanı sıra Tablo 4' te Türkiye' de toplanan vergilerin, TL bazında hiçbir yıl bir önceki yıla göre azalma göstermediği dikkat çekmektedir.

Toplanan vergi gelirleri yıllar içerisinde oransal olarak değişiklik göstermiş olsa da yalnızca 2009 yılında bu artış \%5'in altında \%3,3 olarak gerçekleşmiştir. Vergi geliri artışının en çok olduğu yıllar ise \%41,4 ile 2003, \%26,9 ile 2006 y1lı ve \%20,7 ile 2011 yılı olmuştur. 2018 yılında 738 milyar TL'ye yükselen vergi geliri bir önceki yıla göre \%17,9 artış gösterirken, 2019 yılında 820 milyar TL'ye yükselerek \%11, 2020'de 983 milyar TL'ye yükselerek yaklaşık \%19,9 artış göstermiştir.

Vergi gelirleri dolar bazında hesaplandığında, 2010 yılına kadar 1,5 seviyesinde seyreden ortalama dolar kuru, özellikle 2014 yılından günümüze kadar hızla yükselerek vergi gelirlerini de etkilemiştir. Her ne kadar devletin topladığı vergi gelirleri TL bazında artış gösterse de dolar bazında düşüş göstermiştir. Yıllık ortalama dolar kuru ile hesaplanan gelir vergisinin en çok toplandığı yıl 192 milyar dolar ile 2013 yılı olmuştur. 2016 yılından günümüze kadar her yıl azalan dolar bazındaki vergi geliri, 2020 yılında 140 milyar dolara kadar gerilemiştir. 2002-2020 döneminde toplanan vergi düzeyi dolar bazında toplam 2 trilyon 595 milyara ulaşmıştır.

Tablo 5. 2019-2020 Döneminde Türkiye'de Vergi Gelirlerinin Dağılımı

\begin{tabular}{|c|c|c|c|}
\hline Vergiler & 2019 Bütçe (Milyar TL) & 2020 Bütçe (Milyar TL) & Artiş (\%) \\
\hline Gelir Vergisi & 163.9 & 182.1 & 20.1 \\
\hline ÖTV & 145.2 & 175.2 & 10.9 \\
\hline KDV & 52.1 & 57.8 & 25.1 \\
\hline İthalde Alınan KDV & 126.4 & 158.1 & 15.5 \\
\hline Kurumlar Vergisi & 77.4 & 89.4 & 35.1 \\
\hline Harçlar & 21.9 & 29.6 & 6.4 \\
\hline BSMV & 23.5 & 25 & 14.9 \\
\hline Damga Vergisi & 18.7 & 21.5 & 22.5 \\
\hline MTV & 14.2 & 17.4 & 17.7 \\
\hline Diğer Vergiler & 24.3 & 28.6 & 3.7 \\
\hline
\end{tabular}

Kaynak: Gelir İdaresi Başkanlığı

Tablo 5'te 2019-2020 döneminde Türkiye'de vergi gelirlerinin dağılımına ilişkin veriler yer almaktadır. Türkiye' de devlet tarafından oluşturulan birçok kanun ve bu kanunlar neticesinde toplanan birçok vergi kalemi bulunmaktadır. Bunlardan en yaygın olanları gelir vergisi, kurumlar vergisi, katma değer vergisi, özel tüketim vergisi, motorlu taşıtlar vergisi, iletişim vergisi, emlak vergisi, damga vergisi, şans oyunları vergisi ve dijital hizmet vergisi gibi kalemlerdir. Bu vergi kalemlerinin bazıları yıllar içerisinde yeni bir kanunun yürürlüğe girmesi sonucunda vatandaştan toplanmaya başlanmış olup bazıları uzun yıllardan bu yana vatandaşlardan talep edilmektedir. 2019 yılında gelir vergisi ortalama 164 milyar TL olup 2020 yılında \%11 oranında artarak 182 milyar TL'ye yükselmiştir. Özel tüketim vergisi 2020 yılında 2019 yılına oranla ortalama \%21 oranında artarak 
175 milyar TL'ye, katma değer vergisi ise 2020 yılında 2019 yılına oranla \%11 oranında artarak ortalama olarak 58 milyar TL'ye ulaşmıştır. Tablo 5'te 2020 yılında Türkiye' de tüm vergi türlerine ait gelirlerin 2019 yılına oranla artış gösterdiği dikkat çekmektedir.

Tablo 6. 2002-2020 Döneminde Türkiye'de Vergi Geliri İçinde Vergi Türlerinin Payı

\begin{tabular}{|c|c|c|c|c|}
\hline Y1lar & $\begin{array}{c}\text { Dolayl Vergiler } \\
\mathbf{( \% )}\end{array}$ & $\begin{array}{c}\text { Dolaysı Vergiler } \\
\mathbf{( \% )}\end{array}$ & $\begin{array}{c}\text { Dolayli Vergilerin } \\
\text { GSYH İçindeki } \\
\text { Payları (\%) }\end{array}$ & $\begin{array}{c}\text { Gini Katsayıs Oranı } \\
\mathbf{( \% )}\end{array}$ \\
\hline 2002 & 67 & 33 & 11,2 & 0,440 \\
\hline 2003 & 65 & 35 & 12,4 & 0,420 \\
\hline 2004 & 68 & 32 & 11,1 & 0,400 \\
\hline 2005 & 67 & 33 & 11,5 & 0,380 \\
\hline 2006 & 69 & 31 & 11,3 & 0,428 \\
\hline 2007 & 66 & 34 & 10,9 & 0,406 \\
\hline 2008 & 65 & 35 & 10,5 & 0,405 \\
\hline 2009 & 64 & 36 & 10,7 & 0,415 \\
\hline 2010 & 67 & 33 & 11,8 & 0,402 \\
\hline 2011 & 68 & 32 & 11,7 & 0,404 \\
\hline 2012 & 67 & 33 & 11,2 & 0,402 \\
\hline 2013 & 69 & 31 & 11,6 & 0,400 \\
\hline 2014 & 68 & 32 & 10,8 & 0,391 \\
\hline 2015 & 68 & 32 & 11,1 & 0,397 \\
\hline 2017 & 67 & 33 & 11,1 & 0,404 \\
\hline 2018 & 65 & 35 & 11,0 & 0,405 \\
\hline 2019 & 68 & 32 & 11,6 & 0,408 \\
\hline 2020 & 68 & 32 & 11,6 & 0,395 \\
\hline
\end{tabular}

Kaynak: Gelir İdaresi Başkanlığı, TÜíK.

Tablo 6'da 2002-2020 döneminde Türkiye' de vergi gelirleri içinde vergi türlerinin payı yer almaktadır. Buna göre, dolaylı vergi oranlarının Türkiye'de sürekli artan bir eğilimde olan bir vergi türü olduğu görülmektedir. Söz konusu dönemde vergilerin sürekli arttığ1 gözlenmektedir. Bir ülkede vergileme oranları içinde dolaylı vergi oranlarının yüksek olması o ülkede adaletsiz bir vergileme sistemi olduğunu ve gelir dağılımının adaletsiz olduğunu göstermektedir. Dolayısıyla gini katsayısı oranlarından da anlaşıldığı gibi Türkiye'de mevcut olan vergilendirme yapısı niteliğine bağlı biçimde gelir dağılımı adaletsizliği oldukça yüksek düzeydedir.

Uluslararası sermaye hareketlerinin vergilendirilmesi, çevre vergilerinin büyük bir bölümünün dolaylı vergi niteliği taşımasının yanı sıra, vergi rekabeti amacıyla dolaysız vergilerin oranının azaldığı gözlenmektedir. Dolaylı vergilerin oranındaki artışların altında yatan temel unsurlar kayıt dışılık ve bunun meydana getirdiği olumsuzluklardır. Ülke yönetiminde ihtiyaç duyulan mali kaynak sağlanamayınca oluşan dolaysız vergi toplamadaki yetersizlik, dolaylı vergilerle ikame edilmektedir (TÜSİAD, 2012).

Tablo 7. Türkiye'de Vergi Gelirlerinin Dağılımı

\begin{tabular}{|c|c|}
\hline Vergi Türü & $\%$ \\
\hline Dolaylı Vergiler & 55 \\
\hline Gelir Vergisi & 23 \\
\hline Kurumlar Vergisi & 13 \\
\hline Diğer Vergiler & 9 \\
\hline
\end{tabular}

Kaynak: Gelir İdaresi Başkanlı̆̆ı.

Tablo 7'de Türkiye'de vergi gelirlerinin dağılımına ilişkin veriler 2020 yılı Mayıs ayı için yer almaktadır. Buna göre, dolaylı vergilerin payı \%55, gelir vergisi payı $\% 23$, kurumlar vergisi payı $\% 13$ ve diğer vergilerin payı da $\% 9^{\prime}$ dur. 


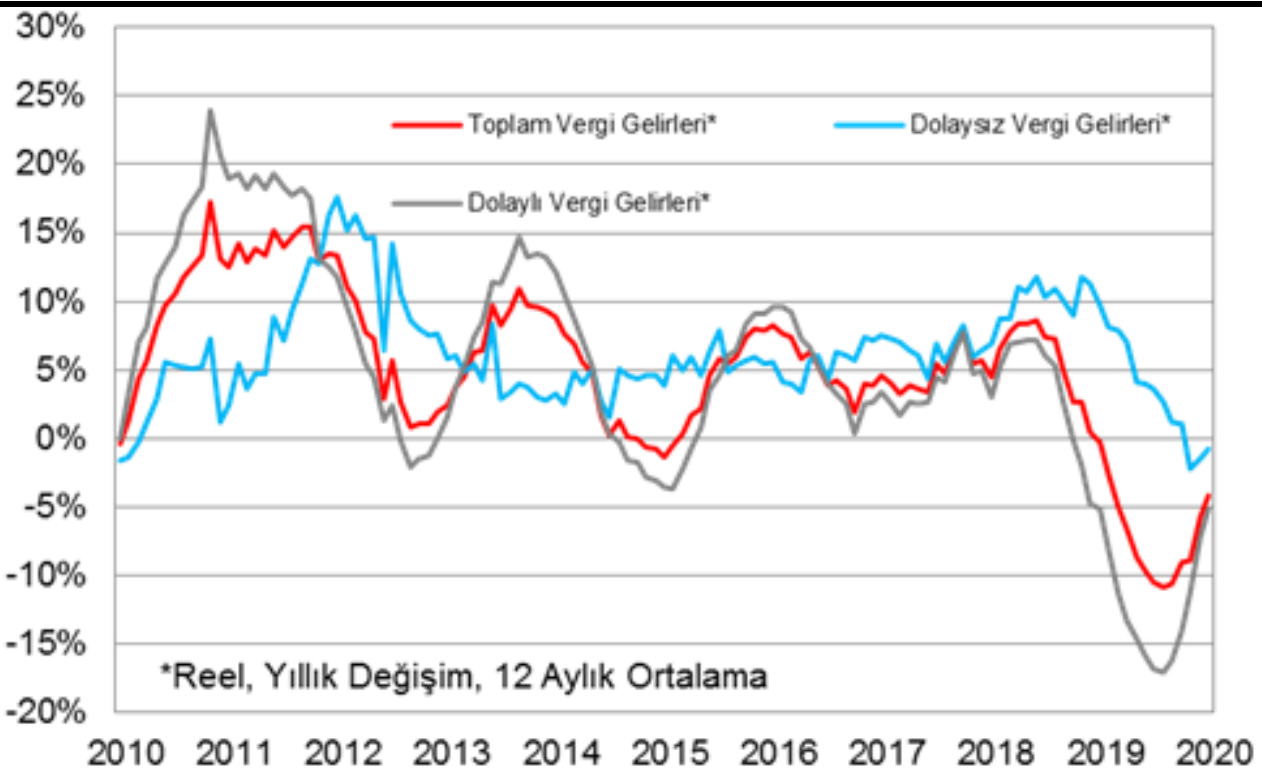

Grafik 1. Türkiye' de Toplam Vergi Gelirleri, Dolaylı ve Dolaysız Vergi Gelirleri

Kaynak: Cumhurbaşkanlığ1 Strateji ve Bütçe Başkanlığı

Grafik 1'de 2010-2020 dönemine ait toplam vergi gelirleriyle dolaylı ve dolaysız vergi gelirlerine ilişkin yıllık değişim oranları yer almaktadır. Toplam vergi gelirleri içerisinde dolaylı vergi gelirlerinin oranının Türkiye'de 2010-2012 döneminde dolaysız vergi gelirleri oranından daha yüksek olduğu görülmektedir. Sonraki dönemde dolaylı vergi gelirlerinde bir artış eğilimi gözlenmekte 2018-2020 döneminde dolaysız vergi gelirlerinin dolaylı vergi gelirlerinden daha yüksek oranda olduğu dikkat çekmektedir.

\section{Dünyada Vergi Yükü}

Vergilendirmenin temel amaçları, devletin kamu harcamalarını finanse etmek, ekonominin sağlıklı bir şekilde işlemesini sağlamak, vergi adaleti yaratmak ve gelir dağılımı sorunu meydana getirmeden ekonomik büyümeyi sağlayan bir yapıya sahip olmaktır. Türkiye vergi yükü ile dolaysız vergi oranları açısından gelişmiş ülkelerle farklılık göstermektedir. Dolaylı vergilerin toplam vergi gelirleri içerisindeki oranı gelişmiş ülkelerde \%30'larda iken, Türkiye'de bu oran \%60'lar düzeyindedir. Dolayısıyla Türkiye'deki vergi yapısıyla dolaylı ve dolaysız vergi dengesi gelir dağılımı adaletini sağlayıcı biçimde değiştirilmelidir (TÜSİAD, 2012).

Tablo 8. 2004-2017 Döneminde Seçili Ülkelerde Toplam Vergi Yükü

\begin{tabular}{|l|l|l|l|l|l|l|l|l|l|l|l|l|l|l|}
\hline Ülkeler & $\mathbf{2 0 0 4}$ & $\mathbf{2 0 0 5}$ & $\mathbf{2 0 0 6}$ & $\mathbf{2 0 0 7}$ & $\mathbf{2 0 0 8}$ & $\mathbf{2 0 0 9}$ & $\mathbf{2 0 1 0}$ & $\mathbf{2 0 1 1}$ & $\mathbf{2 0 1 2}$ & $\mathbf{2 0 1 3}$ & $\mathbf{2 0 1 4}$ & $\mathbf{2 0 1 5}$ & $\mathbf{2 0 1 6}$ & $\mathbf{2 0 1 7}$ \\
\hline Fransa & 42,4 & 42,9 & 43,3 & 42,5 & 42,3 & 41,5 & 42,1 & 43,3 & 44,4 & 45,4 & 45,4 & 45,3 & 45,5 & 46,2 \\
\hline Danimarka & 46,4 & 48,0 & 46,5 & 46,4 & 44,8 & 45,0 & 44,8 & 44,8 & 45,5 & 45,9 & 48,5 & 46,1 & 46,2 & 46,0 \\
\hline Belçika & 43,2 & 43,2 & 43,0 & 42,7 & 43,3 & 42,4 & 42,6 & 43,1 & 44,2 & 45,1 & 45,1 & 44,8 & 44,1 & 44,6 \\
\hline İsvę & 45,7 & 46,6 & 46,0 & 45,0 & 44,0 & 44,1 & 43,2 & 42,5 & 42,6 & 42,9 & 42,6 & 43,1 & 44,0 & 44,0 \\
\hline Finlandiya & 41,8 & 42,1 & 42,2 & 41,5 & 41,2 & 40,9 & 40,8 & 42,0 & 42,7 & 43,6 & 43,8 & 43,9 & 44,0 & 43,3 \\
\hline İtalya & 39,3 & 39,1 & 40,6 & 41,7 & 41,7 & 42,1 & 41,9 & 41,9 & 43,9 & 44,1 & 43,5 & 43,1 & 42,6 & 42,4 \\
\hline Yunanistan & 29,9 & 31,2 & 30,3 & 31,2 & 31,0 & 30,6 & 32,0 & 33,6 & 35,5 & 35,5 & 35,7 & 36,6 & 38,8 & 39,4 \\
\hline Almanya & 33,9 & 33,9 & 34,5 & 34,9 & 35,4 & 36,1 & 35,0 & 35,7 & 36,4 & 36,8 & 36,7 & 37,0 & 37,4 & 37,5 \\
\hline İspanya & 34,1 & 35,1 & 35,9 & 36,4 & 32,1 & 29,7 & 31,2 & 31,2 & 32,1 & 32,9 & 33,6 & 33,6 & 33,2 & 33,7 \\
\hline İngiltere & 32,3 & 32,7 & 32,9 & 33,0 & 32,3 & 31,2 & 32,3 & 33,2 & 32,4 & 32,2 & 31,8 & 32,2 & 32,7 & 33,3 \\
\hline Kanada & 32,8 & 32,8 & 32,8 & 32,6 & 31,3 & 32,4 & 31,1 & 30,9 & 31,3 & 31,2 & 31,3 & 32,7 & 32,7 & 32,2 \\
\hline Yeni Zelanda & 34,2 & 36,1 & 35,3 & 33,9 & 32,9 & 30,2 & 30,3 & 30,1 & 31,6 & 30,5 & 31,2 & 31,6 & 31,6 & 32,0 \\
\hline Japonya & 25,2 & 26,2 & 27,0 & 27,5 & 27,4 & 26,0 & 26,5 & 27,5 & 28,2 & 28,9 & 30,3 & 30,6 & 30,6 & 30,6 \\
\hline İsviçre & 26,6 & 26,6 & 26,4 & 26,2 & 26,6 & 27,0 & 26,6 & 26,9 & 26,9 & 27,0 & 26,9 & 27,6 & 27,8 & 28,5 \\
\hline ABD & 24,6 & 25,9 & 26,7 & 26,7 & 25,7 & 23,0 & 23,5 & 23,9 & 24,1 & 25,7 & 26,0 & 26,2 & 25,9 & 27,1 \\
\hline Kore & 22,0 & 22,5 & 23,6 & 24,8 & 24,6 & 23,8 & 23,4 & 24,2 & 24,8 & 24,3 & 24,6 & 25,2 & 26,2 & 26,9 \\
\hline Türkiye & 23,3 & 23,4 & 23,6 & 23,1 & 23,1 & 23,5 & 24,8 & 25,9 & 24,9 & 25,3 & 24,6 & 25,1 & 25,3 & 24,9 \\
\hline İlanda & 28,9 & 29,4 & 30,8 & 30,4 & 28,5 & 27,3 & 27,0 & 27,4 & 27,6 & 28,2 & 28,4 & 23,1 & 23,3 & 22,8 \\
\hline Meksika & 11,6 & 11,4 & 11,6 & 12,0 & 12,6 & 12,5 & 12,8 & 12,8 & 12,6 & 13,3 & 13,7 & 15,9 & 16,6 & 16,2 \\
\hline
\end{tabular}


Tablo 8' de 2004-2017 dönemi için seçili ülkelerde toplam vergi yükü oranları yer almaktadır. Buna göre Türkiye' nin vergi yükünün diğer ülkelere oranla daha düşük olduğu dikkat çekmektedir. Ancak bu durumun ortaya çıkmasında Türkiye'de vergi yapısının ağırlıklı olarak dolaylı vergilerden oluşması önemli rol oynamaktadır. Seçili ülkeler içerisinde 2017 yılında en yüksek vergi yükünün sırasıyla Fransa $(\% 46,2)$, Danimarka $(\% 46,0)$ ve Belçika'da $(\% 44,6)$ gerçekleştiği görülmektedir. Seçili ülkeler arasında vergi yükü en düşük olan ülkelerin sırasıyla Meksika $(\% 16,2)$, İlanda $(\% 22,8)$ ve Türkiye $(\% 24,9)$ olduğu gözlenmektedir.

Tablo 9. OECD Ülkelerinde Vergi Yükü Dağılımı (\%)

\begin{tabular}{|c|c|c|c|c|c|c|c|c|}
\hline Ülkeler & \begin{tabular}{|c|} 
Gelir ve \\
Kazançlar \\
Üzerinden \\
Alınan Vergiler \\
\end{tabular} & $\begin{array}{c}\text { Sosyal } \\
\text { Güvenlik } \\
\text { Primleri }\end{array}$ & \begin{tabular}{|c|} 
Bordro \\
Üzerinden \\
Alınan Vergiler
\end{tabular} & $\begin{array}{l}\text { Mülkiyet } \\
\text { Üzerinden } \\
\text { Alınan } \\
\text { Vergiler } \\
\end{array}$ & $\begin{array}{c}\text { Mal ve Hizmet } \\
\text { Üzerinden } \\
\text { Alınan Vergiler }\end{array}$ & $\begin{array}{c}\text { Diğer } \\
\text { Vergiler }\end{array}$ & $\begin{array}{c}\text { Gümrük } \\
\text { Vergileri } \\
\text { (AB } \\
\text { Ülkeleri) }\end{array}$ & $\begin{array}{c}\text { Toplam/ } \\
\text { GSYH }\end{array}$ \\
\hline Fransa & 10,9 & 16,8 & 1,6 & 4,4 & 11,3 & 1,2 & 0,1 & 46,2 \\
\hline Danimarka & 29,1 & 0,0 & 0,3 & 1,8 & 14,6 & 0,0 & 0,1 & 46,0 \\
\hline Belçika & 16,3 & 13,6 & 0,0 & 3,5 & 10,8 & 0,0 & 0,4 & 44,6 \\
\hline İsveç & 15,8 & 9,7 & 5,1 & 1,0 & 12,3 & 0,0 & 0,1 & 44,0 \\
\hline Finlandiya & 15,4 & 12,1 & 0,0 & 1,5 & 14,2 & 0,0 & 0,1 & 43,3 \\
\hline İtalya & 13,4 & 12,9 & 0,0 & 2,6 & 12,0 & 1,3 & 0,1 & 42,4 \\
\hline Avusturya & 11,8 & 14,5 & 2,8 & 0,5 & 11,8 & 0,2 & 0,1 & 41,8 \\
\hline Yunanistan & 9,0 & 11,7 & 0,0 & 3,2 & 15,4 & 0,0 & 0,2 & 39,4 \\
\hline Hollanda & 11,6 & 13,8 & 0,0 & 1,6 & 11,3 & 0,1 & 0,3 & 38,8 \\
\hline Lüksemburg & 14,4 & 11,1 & 0,0 & 3,7 & 9,4 & 0,1 & 0,0 & 38,7 \\
\hline Norveç & 14,6 & 10,4 & 0,1 & 1,3 & 11,9 & 0,0 & - & 38,2 \\
\hline Macaristan & 6,9 & 12,8 & 0,7 & 1,1 & 16,0 & 0,1 & 0,1 & 37,7 \\
\hline İzlanda & 18,6 & 3,5 & 0,3 & 2,0 & 12,6 & 0,7 & - & 37,7 \\
\hline Almanya & 12,2 & 14,2 & 0,0 & 1,0 & 9,9 & 0,1 & 0,2 & 37,5 \\
\hline Slovenya & 6,9 & 14,4 & 0,0 & 0,6 & 13,9 & 0,0 & 0,1 & 36,0 \\
\hline Çek Cum. & 7,7 & 15,0 & 0,0 & 0,5 & 11,5 & 0,0 & 0,2 & 34,9 \\
\hline Portekiz & 9,8 & 9,3 & 0,0 & 1,4 & 13,8 & 0,3 & 0,1 & 34,7 \\
\hline Polonya & 6,9 & 12,9 & 0,0 & 1,2 & 11,7 & 1,2 & - & 33,9 \\
\hline İspanya & 9,7 & 11,5 & 0,0 & 2,5 & 9,8 & 0,0 & 0,2 & 33,7 \\
\hline İngiltere & 11,9 & 6,4 & 0,1 & 4,2 & 10,5 & 0,0 & 0,2 & 33,3 \\
\hline Estonya & 7,2 & 11,2 & 0,0 & 0,2 & 14,2 & 0,0 & 0,2 & 33,0 \\
\hline Slovakya & 6,8 & 14,5 & 0,0 & 0,4 & 11,0 & 0,0 & 0,2 & 32.9 \\
\hline İsrail & 11,6 & 5,3 & 1,2 & 3,3 & 11,3 & 0,0 & - & 32,7 \\
\hline Kanada & 15,4 & 4,6 & 0,7 & 3,8 & 7,7 & 0,0 & - & 32,2 \\
\hline Yeni Zelanda & 17,8 & 0,0 & 0,0 & 1,9 & 12,3 & 0,0 & - & 32,0 \\
\hline Japonya & 9,7 & 12,4 & 0,0 & 2,5 & 6,1 & 0,1 & - & 30,6 \\
\hline Letonya & 8,2 & 8,4 & 0,0 & 1,0 & 12,6 & 0,0 & 0,2 & 30,4 \\
\hline Litvanya & 5,4 & 12,3 & 0,0 & 0,4 & 11,5 & 0,0 & 0,2 & 29,8 \\
\hline İsviçre & 13,2 & 6,7 & 0,0 & 2,0 & 6,4 & 0,1 & - & 28,5 \\
\hline Avustralya & 15,9 & 0,0 & 1,4 & 3,0 & 7,5 & 0,0 & - & 27,8 \\
\hline ABD & 12,4 & 6,3 & 0,0 & 4,2 & 4,3 & 0,0 & - & 27,1 \\
\hline Kore & 8,6 & 6,9 & 0,1 & 3,1 & 7,5 & 0,7 & - & 26,9 \\
\hline Türkiye & 5,3 & 7,3 & 0,0 & 1,1 & 10,8 & 0,3 & - & 24,9 \\
\hline İrlanda & 9,9 & 3,9 & 0,1 & 1,3 & 7,4 & 0,0 & 0,1 & 22,8 \\
\hline Şili & 7,0 & 1,5 & 0,0 & 1,1 & 11,0 & $-0,4$ & - & 20,2 \\
\hline Meksika & 7,2 & 2,1 & 0,4 & 0,3 & 6,4 & 0,2 & - & 16,2 \\
\hline OECD-Ortalama & 11,4 & 9,3 & 0,4 & 1,9 & 11,1 & 0,2 & 0,2 & 34,2 \\
\hline
\end{tabular}

Tablo 9' da OECD ülkeleri için 2017 yılına ait vergi yükü (vergi gelirleri/GSYH) dağılımı (mahalli idare vergi gelirleri dâhil) verileri görülmektedir. Buna göre gelir ve kazançlar üzerinden alınan vergilerin en yüksek olduğu $(\% 29,1)$ ülke Danimarka iken gelir ve kazançlar üzerinden alınan vergilerin en düşük olduğu $(\% 5,3)$ ülke Türkiye' dir. Sosyal güvenlik primleri üzerinden alınan en yüksek vergi \%16,8 ile Fransa' dadır. Bordro üzerinden alınan vergilerin en fazla $(\% 1,6)$ olduğu ülke Fransa, en düşük $(\% 1,5)$ olduğu ülke ise Şili'dir. Mülkiyet üzerinden alınan vergilerin en yüksek $(\% 4,4)$ olduğu ülke en fazla vergi yüküne sahip olan Fransa olup mülkiyet üzerinden alınan en düşük vergi $(\% 0,3)$ Meksika'dadır. Mal ve hizmet üzerinden alınan vergilerin en fazla $(\% 16,0)$ olduğu ülke Macaristan iken en düşük $(\% 4,3)$ olduğu ülkenin de ABD olduğu görülmektedir. Vergi yükü en fazla $(\% 46,2)$ olan ülke Fransa, vergi yükü en düşük $(\% 16,2)$ olan ülke de Meksika' dır. 
Tablo 10. OECD Ülkelerinde Mahalli İdareler Dâhil Gelir ve Kazançlar Üzerindeki Vergi Yükü

$(\%)$

\begin{tabular}{|c|c|c|}
\hline Ülkeler & $\begin{array}{c}\text { Sosyal Güvenlik Primleri Dâhil } \\
\text { (Gelir ve Kazançlar Üzerindeki Vergi/GSYH) }\end{array}$ & $\begin{array}{c}\text { Sosyal Güvenlik Primleri Hariç } \\
\text { (Gelir ve Kazançlar Üzerindeki Vergi/GSYH) }\end{array}$ \\
\hline Belçika & 29,9 & 16,3 \\
\hline Danimarka & 29,1 & 29,1 \\
\hline Fransa & 27,7 & 10,9 \\
\hline Finlandiya & 27,5 & 15,4 \\
\hline Almanya & 26,5 & 12,2 \\
\hline Avusturya & 26,4 & 11,8 \\
\hline İtalya & 26,3 & 13,4 \\
\hline Hollanda & 25,5 & 11,6 \\
\hline Lüksemburg & 25,4 & 14,4 \\
\hline İsveç & 25,4 & 15,8 \\
\hline Norveç & 25,0 & 14,6 \\
\hline Çek Cumhuriyeti & 22,8 & 7,7 \\
\hline İzlanda & 22,1 & 18,6 \\
\hline Japonya & 22,1 & 9,7 \\
\hline Slovakya & 21,3 & 6,8 \\
\hline Slovenya & 21,3 & 6,9 \\
\hline İspanya & 21,2 & 9,7 \\
\hline Yunanistan & 20,6 & 9,0 \\
\hline Kanada & 20,0 & 15,4 \\
\hline İsviçre & 19,9 & 13,2 \\
\hline Polonya & 19,8 & 6,9 \\
\hline Macaristan & 19,7 & 6,9 \\
\hline Portekiz & 19,1 & 9,8 \\
\hline $\mathrm{ABD}$ & 18,7 & 12,4 \\
\hline Estonya & 18,4 & 7,2 \\
\hline İngiltere & 18,3 & 11,9 \\
\hline Yeni Zelanda & 17,8 & 17,8 \\
\hline Litvanya & 17,7 & 5,4 \\
\hline İsrail & 16,9 & 11,6 \\
\hline Letonya & 16,6 & 8,2 \\
\hline Avustralya & 15,9 & 15,9 \\
\hline Kore & 15,6 & 8,6 \\
\hline İ́rlanda & 13,8 & 9,9 \\
\hline Türkiye & 12,6 & 5,3 \\
\hline Meksika & 9,4 & 7,2 \\
\hline Şili & 8,4 & 7,0 \\
\hline OECD Ortalama & 20,7 & 11,4 \\
\hline
\end{tabular}

Kaynak: OECD

Tablo 10' da 2017 yılı için OECD ülkelerinde mahalli idareler dâhil gelir ve kazançlar üzerindeki vergi yükü verileri yer almaktadır. Buna göre sosyal güvenlik primleri dâhil (gelir ve kazançlar üzerindeki vergi/GSYH) oranı en yüksek $(\% 29,9)$ olan ülkenin Belçika, en düşük $(\% 8,4)$ olan ülkenin de Şili olduğu gözlenmektedir. Sosyal güvenlik primleri hariç (gelir ve kazançlar üzerindeki vergi/GSYH) oranı en yüksek $(\% 29,1)$ olan ülkenin Danimarka, en düşük $(\% 5,3)$ olan ülkenin de Türkiye olduğu dikkat çekmektedir.

Tablo 11. OECD Ülkelerinde Mal ve Hizmetler Üzerindeki Vergi Yükü (Dolaylı Vergiler)

\begin{tabular}{|c|c|}
\hline Ülkeler & $\begin{array}{c}\text { Mal ve Hizmetlerden Alınan Vergi/GSYH } \\
\text { (Mahalli İdare Vergi Gelirleri Dâhil) }\end{array}$ \\
\hline Belçika & 10,8 \\
\hline Danimarka & 14,6 \\
\hline Fransa & 11,3 \\
\hline Finlandiya & 14,2 \\
\hline Almanya & 9,9 \\
\hline Avusturya & 11,8 \\
\hline İtalya & 12,0 \\
\hline Hollanda & 11,3 \\
\hline Lüksemburg & 9,4 \\
\hline İsveç & 12,3 \\
\hline Norveç & 11,9 \\
\hline Çek Cumburiyeti & 11,5 \\
\hline İzlanda & 12,6 \\
\hline
\end{tabular}




\begin{tabular}{|c|c|}
\hline Ülkeler & $\begin{array}{c}\text { Mal ve Hizmetlerden Alınan Vergi/GSYH } \\
\text { (Mahalli İdare Vergi Gelirleri Dâhil) }\end{array}$ \\
\hline Japonya & 6,1 \\
\hline Slovakya & 11,0 \\
\hline Slovenya & 13,9 \\
\hline İspanya & 9,8 \\
\hline Yunanistan & 15,4 \\
\hline Kanada & 7,7 \\
\hline İsviçre & 6,4 \\
\hline Polonya & 11,7 \\
\hline Macaristan & 16,0 \\
\hline Portekiz & 13,8 \\
\hline $\mathrm{ABD}$ & 4,3 \\
\hline Estonya & 14,2 \\
\hline İngiltere & 10,5 \\
\hline Yeni Zelanda & 12,3 \\
\hline Litvanya & 11,5 \\
\hline İsrail & 11,3 \\
\hline Letonya & 12,6 \\
\hline Avustralya & 7,5 \\
\hline Kore & 7,5 \\
\hline İrlanda & 7,4 \\
\hline Türkiye & 11,0 \\
\hline Meksika & 6,4 \\
\hline Şili & 11,0 \\
\hline OECD Ortalama & 11,1 \\
\hline
\end{tabular}

Tablo 11'de OECD ülkelerinde 2017 yılına ait mal ve hizmetler üzerindeki vergi yükü (dolaylı vergiler) verileri yer almaktadır. Buna göre mal ve hizmetler üzerindeki vergi yükü (dolaylı vergiler) oranı en fazla olan ülkelerin sirasiyla Macaristan (\%16,0), Yunanistan (\%15,4), Danimarka $(\% 14,6)$, Finlandiya $(\% 14,2)$ ve Estonya $(\% 14,2)$ olduğu görülmektedir. Mal ve hizmetler üzerindeki vergi yükü (dolaylı vergiler) oranı en düşük olan ülkelerin de sırasıyla ABD $(\% 4,3)$, Japonya $(\% 6,1)$, İsviçre $(\% 6,4)$, Meksika $(\% 6,4)$ ve İrlanda $(\% 7,4)$ olduğu gözlenmektedir. 2017 yılında Türkiye' de \%11 olan bu oran 2020 yılında \%11,8'e yükselmiştir.

Tablo 12. OECD Ülkelerinde Dolaylı ve Dolaysız Vergilerin Toplam Vergiler İçindeki Payı (Mahalli İdare Vergi Gelirleri ve Payları Dâhil)

\begin{tabular}{|c|c|c|c|c|c|}
\hline \multicolumn{3}{|c|}{$\begin{array}{c}\text { Vergi Gelirleri + Sosyal Güvenlik Primleri/ } \\
\text { Toplam Vergi }\end{array}$} & \multicolumn{3}{|c|}{$\begin{array}{l}\text { Vergi Gelirleri/ } \\
\text { Toplam Vergi }\end{array}$} \\
\hline Ülkeler & $\begin{array}{c}\text { Dolaysız } \\
\text { Vergi/Toplam } \\
\text { Vergi }\end{array}$ & $\begin{array}{c}\text { Dolaylı } \\
\text { Vergi/Toplam } \\
\text { Vergi }\end{array}$ & Ülke & $\begin{array}{c}\text { Dolaysız } \\
\text { Vergi/Toplam } \\
\text { Vergi }\end{array}$ & $\begin{array}{c}\text { Dolaylı } \\
\text { Vergi/Toplam } \\
\text { Vergi }\end{array}$ \\
\hline $\mathrm{ABD}$ & 84,2 & 15,9 & $\mathrm{ABD}$ & 79,4 & 20,6 \\
\hline Japonya & 79,6 & 20,4 & Avustralya & 72,9 & 27,1 \\
\hline İsviçre & 77,7 & 22,3 & Kanada & 72,0 & 28,0 \\
\hline Kanada & 76,0 & 24,0 & İsviçre & 70,8 & 29,2 \\
\hline Belçika & 75,7 & 24,3 & Danimarka & 68,1 & 31,9 \\
\hline Lüksemburg & 75,7 & 24,3 & Lüksemburg & 65,9 & 34,1 \\
\hline Fransa & 75,6 & 24,4 & Japonya & 65,7 & 34,3 \\
\hline Almanya & 73,8 & 26,2 & Belçika & 65,1 & 34,9 \\
\hline Avustralya & 72,9 & 27,1 & İsveç & 64,1 & 35,9 \\
\hline Kore & 72,3 & 27,7 & İzlanda & 63,3 & 36,7 \\
\hline İsveç & 72,0 & 28,0 & Kore & 62,7 & 37,3 \\
\hline Avusturya & 71,8 & 28,2 & Yeni Zelanda & 61,6 & 38,4 \\
\hline İtalya & 71,6 & 28,4 & Fransa & 61,6 & 38,4 \\
\hline İspanya & 70,9 & 29,1 & İngiltere & 61,0 & 39,0 \\
\hline Hollanda & 70,9 & 29,1 & İrlanda & 60,8 & 39,2 \\
\hline Norveç & 68,9 & 31,1 & İtalya & 59,1 & 40,9 \\
\hline İngiltere & 68,5 & 31,5 & İsrail & 58,7 & 41,3 \\
\hline Danimarka & 68,1 & 31,9 & Almanya & 57,7 & 42,3 \\
\hline İrlanda & 67,5 & 32,5 & Norveç & 57,3 & 42,7 \\
\hline Finlandiya & 67,2 & 32,8 & Avusturya & 56,8 & 43,2 \\
\hline Çek Cum. & 67,1 & 32,9 & İspanya & 55,8 & 44,2 \\
\hline İzlanda & 66,7 & 33,3 & Meksika & 55,4 & 44,6 \\
\hline Slovakya & 66,6 & 33,4 & Hollanda & 54,7 & 45,3 \\
\hline
\end{tabular}




\begin{tabular}{|c|c|c|c|c|c|}
\hline \multicolumn{2}{|c|}{ Vergi Gelirleri + Sosyal Güvenlik Primleri/ } & \multicolumn{3}{c|}{$\begin{array}{c}\text { Vergi Gelirleri/ } \\
\text { Toplam Vergi }\end{array}$} \\
\hline & $\begin{array}{c}\text { Toplam Vergi } \\
\text { Dolaysız } \\
\text { Vergi/Toplam } \\
\text { Vergi }\end{array}$ & $\begin{array}{c}\text { Dolayll } \\
\text { Vergi/Toplam } \\
\text { Vergi }\end{array}$ & Ülke & $\begin{array}{c}\text { Dolaysiz } \\
\text { Vergi/Toplam } \\
\text { Vergi }\end{array}$ & $\begin{array}{c}\text { Dolayli } \\
\text { Vergi/Toplam } \\
\text { Vergi }\end{array}$ \\
\hline Polonya & 65,6 & 34,4 & Finlandiya & 54,5 & 45,5 \\
\hline İsrail & 65,3 & 34,7 & Portekiz & 45,7 & 54,3 \\
\hline Yeni Zelanda & 61,6 & 38,4 & Polonya & 44,6 & 55,4 \\
\hline Litvanya & 61,5 & 38,5 & Yunanistan & 44,5 & 55,5 \\
\hline Slovenya & 61,4 & 38,6 & Letonya & 42,8 & 57,2 \\
\hline Meksika & 61,2 & 38,8 & Çek Cum. & 42,3 & 57,7 \\
\hline Yunanistan & 60,9 & 39,1 & Şili & 40,9 & 59,1 \\
\hline Portekiz & 60,2 & 39,8 & Slovakya & 40,2 & 59,8 \\
\hline Letonya & 58,6 & 41,4 & Türkiye & 38,5 & 61,5 \\
\hline Macaristan & 57,5 & 42,5 & Macaristan & 35,8 & 64,2 \\
\hline Estonya & 57,1 & 42,9 & Slovenya & 35,6 & 64,4 \\
\hline Türkiye & 56,6 & 43,4 & Estonya & 35,1 & 64,9 \\
\hline Şili & 45,2 & 54,8 & Litvanya & 34,4 & 65,6 \\
\hline OECD-Ortalama & 67,6 & 32,4 & OECD-Ortalama & 55,2 & \\
\hline
\end{tabular}

\section{Kaynak: OECD}

2017 yılı için vergi gelirleriyle sosyal güvenlik primlerinin toplamının toplam vergi tutarına oranı baz alınarak hesaplanan toplam vergiler içerisindeki dolaysız vergilerin oranının en yüksek $(\% 84,2)$ olduğu ülkenin ABD olduğu görülmektedir. ABD'yi sırasıyla Japonya $(\% 79,6)$, İsviçre $(\% 77,7)$, Kanada $(\% 76,0)$ ve Belçika $(\% 75,7)$ takip etmektedir. Toplam vergiler içerisindeki dolaysız vergilerin oranının en düşük $(\% 45,2)$ olduğu ülke Şili'dir. Şili'yi sırasıyla Türkiye $(\% 56,6)$, Estonya $(\% 57,1)$, Macaristan $(\% 57,5)$ ve Letonya $(\% 58,6)$ izlemektedir. Vergi gelirlerinin toplam vergi tutarina oranı üzerinden hesaplanan dolaysız vergi/toplam vergi oranı en yüksek olan ülkeler sırasıyla ABD $(\% 79,4)$, Avustralya $(\% 72,9)$, Kanada $(\% 72,0)$, İsviçre $(\% 70,8)$ ve Danimarka $(\% 68,1)$ 'dır. Dolaysız vergi/toplam vergi oranı en düşük olan ülkelerin sırasiyla Litvanya $(\% 34,4)$, Estonya $(\% 35,1)$, Slovenya $(\% 35,6)$ ve Macaristan $(\% 35,8)$ olduğu gözlenmektedir.

Tablo 13. OECD Ülkelerinde Dolaylı ve Dolaysız Vergilerin GSYH'ye Oranı (Mahalli İdare Vergi Gelirleri ve Payları Dâhil)

\begin{tabular}{|c|c|c|c|c|c|c|c|}
\hline \multicolumn{2}{|c|}{ Vergi Gelirleri + Sosyal Güvenlik Primleri/GSYH } & \multicolumn{4}{|c|}{ Vergi Gelirleri/GSYH } \\
\hline Ülkeler & $\begin{array}{c}\text { Dolaysız } \\
\text { Vergi }\end{array}$ & $\begin{array}{c}\text { Dolaylı } \\
\text { Vergi }\end{array}$ & Toplam & Ülke & $\begin{array}{c}\text { Dolays1z } \\
\text { Vergi }\end{array}$ & Dolaylı Vergi & Toplam \\
\hline Fransa & 34,9 & 11,3 & 46,2 & Danimarka & 31,3 & 14,6 & 45,9 \\
\hline Danimarka & 31,3 & 14,6 & 46,0 & İsveç & 22,0 & 12,3 & 34,3 \\
\hline Belçika & 33,8 & 10,8 & 44,6 & İzlanda & 21,6 & 12,6 & 34,2 \\
\hline İsveç & 31,7 & 12,3 & 44,0 & Yeni Zelanda & 19,7 & 12,3 & 32,0 \\
\hline Finlandiya & 29,1 & 14,2 & 43,3 & Finlandiya & 17,0 & 14,2 & 31,2 \\
\hline İtalya & 30,3 & 12,0 & 42,4 & Belçika & 20,2 & 10,8 & 31,0 \\
\hline Avusturya & 30,0 & 11,8 & 41,8 & İtalya & 17,4 & 12,0 & 29,5 \\
\hline Yunanistan & 24,0 & 15,4 & 39,4 & Fransa & 18,1 & 11,3 & 29,4 \\
\hline Hollanda & 27,5 & 11,3 & 38,8 & Norveç & 16,0 & 11,9 & 27,9 \\
\hline Lüksemburg & 29,2 & 9,4 & 38,7 & Avustralya & 20,2 & 7,5 & 27,8 \\
\hline Norveç & 26,3 & 11,9 & 38,2 & Yunanistan & 12,3 & 15,4 & 27,7 \\
\hline Macaristan & 21,7 & 16,0 & 37,7 & Kanada & 19,9 & 7,7 & 27,6 \\
\hline İzlanda & 25,1 & 12,6 & 37,7 & Lüksemburg & 18,2 & 9,4 & 27,6 \\
\hline Almanya & 27,7 & 9,9 & 37,5 & İsrail & 16,1 & 11,3 & 27,4 \\
\hline Slovenya & 22,1 & 13,9 & 36,0 & Avusturya & 15,5 & 11,8 & 27,2 \\
\hline Çek Cum. & 23,4 & 11,5 & 34,9 & İniltere & 16,4 & 10,5 & 26,9 \\
\hline Portekiz & 20,9 & 13,8 & 34,7 & Portekiz & 11,6 & 13,8 & 25,4 \\
\hline Polonya & 22,2 & 11,7 & 33,9 & Macaristan & 8,9 & 16,0 & 24,9 \\
\hline İspanya & 23,9 & 9,8 & 33,7 & Hollanda & 13,6 & 11,3 & 24,9 \\
\hline İngiltere & 22,8 & 10,5 & 33,3 & Almanya & 13,5 & 9,9 & 23,3 \\
\hline Estonya & 18,8 & 14,2 & 33,0 & İspanya & 12,4 & 9,8 & 22,2 \\
\hline Slovakya & 21,9 & 11,0 & 32,9 & Letonya & 9,4 & 12,6 & 22,0 \\
\hline İsrail & 21,4 & 11,3 & 32,7 & Estonya & 7,6 & 14,2 & 21,8 \\
\hline Kanada & 24,5 & 7,7 & 32,2 & İsviçre & 15,4 & 6,4 & 21,8 \\
\hline Yeni Zelanda & 19,7 & 12,3 & 32,0 & Slovenya & 7,7 & 13,9 & 21,6 \\
\hline Japonya & 24,5 & 6,1 & 30,6 & Polonya & 9,4 & 11,7 & 21,0 \\
\hline Letonya & 17,8 & 12,6 & 30,4 & ABD & 16,6 & 4,3 & 20,9 \\
\hline Litvanya & 18,4 & 11,5 & 29,8 & Kore & 12,5 & 7,5 & 20,0 \\
\hline
\end{tabular}




\begin{tabular}{|c|c|c|c|c|c|c|c|}
\hline \multicolumn{2}{|c|}{ Vergi Gelirleri + Sosyal Güvenlik Primleri/GSYH } & \multicolumn{4}{c|}{ Vergi Gelirleri/GSYH } \\
\hline Ülkeler & $\begin{array}{c}\text { Dolaysız } \\
\text { Vergi }\end{array}$ & $\begin{array}{c}\text { Dolayl } \\
\text { Vergi }\end{array}$ & Toplam & Ülke & $\begin{array}{c}\text { Dolaysız } \\
\text { Vergi }\end{array}$ & Dolaylı Vergi & Toplam \\
\hline İviçre & 22,1 & 6,4 & 28,5 & Çek Cum. & 8,4 & 11,5 & 19,9 \\
\hline Avustralya & 20,2 & 7,5 & 27,8 & İlanda & 11,5 & 7,4 & 19,0 \\
\hline ABD & 22,8 & 4,3 & 27,1 & Şili & 7,7 & 11,0 & 18,7 \\
\hline Kore & 19,4 & 7,5 & 26,9 & Slovakya & 7,4 & 11,0 & 18,4 \\
\hline Türkiye & 14,1 & 10,8 & 24,9 & Japonya & 12,1 & 6,1 & 18,2 \\
\hline İrlanda & 15,4 & 7,4 & 22,8 & Türkiye & 6,8 & 10,8 & 17,6 \\
\hline Şili & 9,1 & 11,0 & 20,2 & Litvanya & 6,0 & 11,5 & 17,5 \\
\hline Meksika & 9,7 & 6,4 & 16,2 & Meksika & 7,6 & 6,4 & 14,0 \\
\hline OECD-Ortalama & 23,1 & 11,1 & 34,2 & OECD-Ortalama & 14,0 & 11,1 & 25,0 \\
\hline
\end{tabular}

Tablo 13'te 2017 yılında OECD ülkelerinde dolaylı ve dolaysız vergilerin GSYH'ye oranı görülmektedir. Vergi gelirleriyle sosyal güvenlik primleri toplamının GSYH'ye oranı üzerinden hesaplanan dolaylı ve dolaysız vergilerin GSYH'ye oranı en yüksek olan ülkeler sırasıyla Fransa $(\% 46,2)$, Danimarka $(\% 46,0)$, Belçika $(\% 44,6)$, İsveç $(\% 44,0)$ ve Finlandiya $(\% 43,3)^{\prime}$ dır. Dolaylı ve dolaysız vergilerin GSYH'ye oranı en düşük olan ülkeler ise sırasıyla Meksika (\%16,2), Şili (\% 20,2), İrlanda $(\% 22,8)$, Türkiye $(\% 24,9)$ ve Kore $(\% 26,9)^{\prime}$ dir. Vergi gelirlerinin GSYH'ye oranı üzerinden hesaplanan dolaylı ve dolaysız vergilerin toplamının GSYH'ye oranı en yüksek olan ülkeler sırasıyla Danimarka (\%45,9), İsveç (\%34,3), İzlanda (\%34,2), Yeni Zelanda $(\% 32,0)$ ve Finlandiya $(\% 31,2)^{\prime}$ dır. Vergi gelirlerinin GSYH'ye oranı üzerinden hesaplanan dolaylı ve dolaysız vergilerin toplamının GSYH'ye oranı en düşük olan ülkeler ise sirasiyla Meksika $(\% 14,0)$, Litvanya $(\% 17,5)$, Türkiye $(\% 17,6)$, Japonya $(\% 18,2)$ ve Slovakya $(\% 18,4)^{\prime}$ dır.

Tablo 14. OECD Ülkelerinde Ortalama Ücretin Vergi Yükü (Evli ve İki Çocuklu)

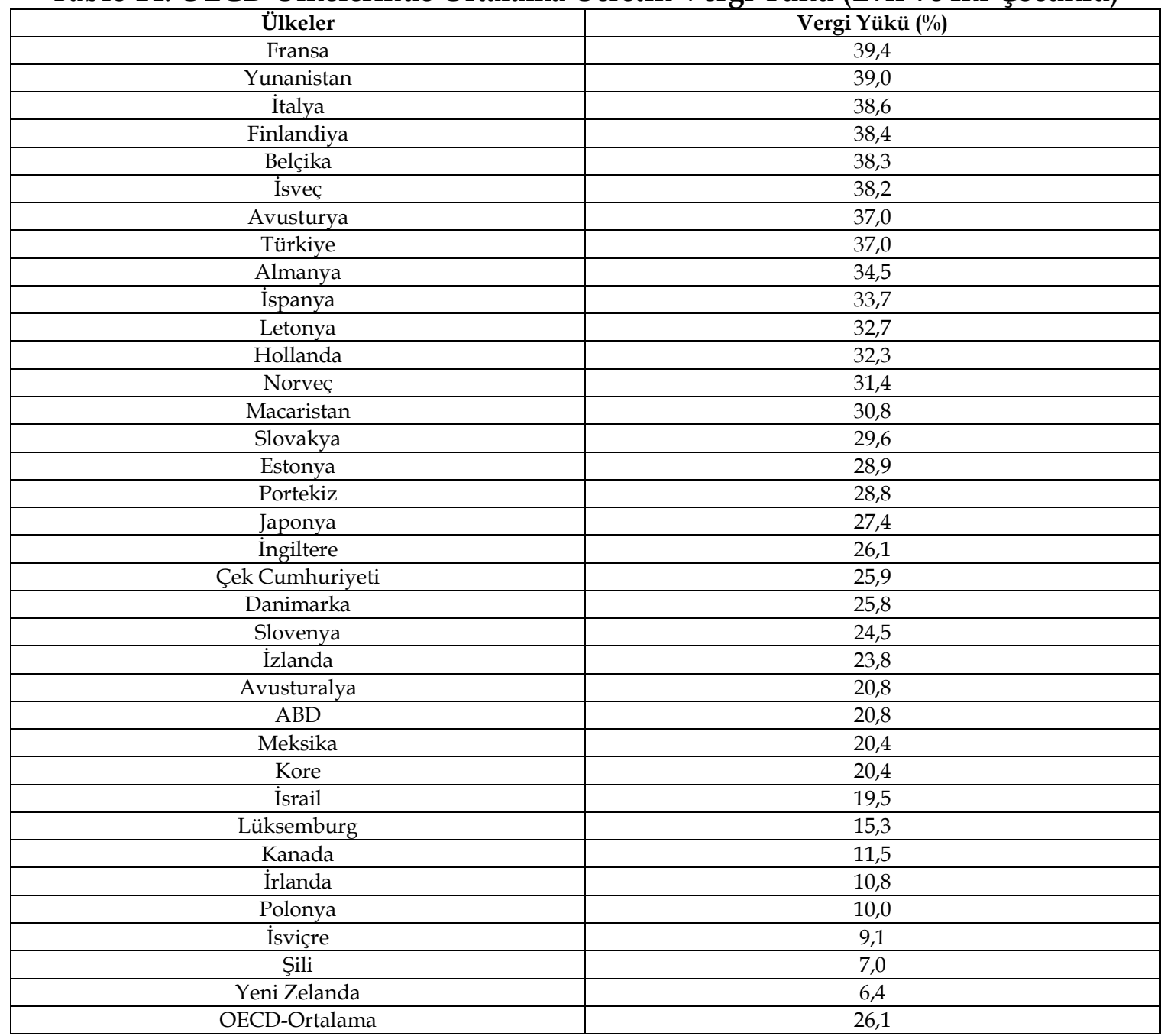


OECD ülkeleri için 2017 yılına ait ortalama ücretin vergi yükü (evli ve iki çocuklu) oranları değerlendirildiğinde en yüksek vergi yükü oranının $(\% 39,4)$ Fransa'da olduğu görülmektedir. Fransa'yı Yunanistan $(\% 39,0)$, İtalya $(\% 38,6)$, Finlandiya $(\% 38,4)$, Belçika $(\% 38,3)$ ve İsveç $(\% 38,2)$ izlemektedir. Ortalama ücretin vergi yükü (evli ve iki çocuklu) oranı en düşük olan ülkelerin Yeni Zelanda $(\% 6,4)$, Şili $(\% 7,0)$, İsviçre $(\% 9,1)$, Polonya $(\% 10,0)$ ve İrlanda $(\% 10,8)$ olduğu gözlenmektedir.

Tablo 15. OECD Ülkelerinde İşverene Maliyetinin Vergi Yükü (2017)

\begin{tabular}{|c|c|c|}
\hline Ülkeler & Evli ve İki Çocuklu İçin (\%) & Ortalama Ücret Alan Bekar Calıșan İçin (\%) \\
\hline Belçika & 38,3 & 53,7 \\
\hline Finlandiya & 38,4 & 42,9 \\
\hline İtalya & 38,6 & 47,7 \\
\hline Hollanda & 32,3 & 37,5 \\
\hline Lüksemburg & 15,3 & 36,7 \\
\hline Norveç & 31,4 & 35,9 \\
\hline Macaristan & 30,8 & 46,2 \\
\hline İzlanda & 23,8 & 33,2 \\
\hline Portekiz & 28,8 & 41,4 \\
\hline Polonya & 10,0 & 35,6 \\
\hline İspanya & 33,7 & 39,3 \\
\hline İngiltere & 26,1 & 30,9 \\
\hline Estonya & 28,9 & 39,0 \\
\hline Slovakya & 29,6 & 41,6 \\
\hline İsrail & 19,5 & 22,1 \\
\hline Kanada & 11,5 & 30,9 \\
\hline Yeni Zelanda & 6,4 & 18,1 \\
\hline Japonya & 27,4 & 32,6 \\
\hline Şili & 7,0 & 7,0 \\
\hline Meksika & 20,4 & 20,4 \\
\hline OECD-Ortalama & 26,1 & 35,9 \\
\hline
\end{tabular}

Kaynak: OECD

Tablo 15'te 2017 yılına ait evli ve iki çocuklu ile ortalama ücret alan bekâr çalışan için işveren maliyetinin vergi yükü dağılımı OECD ülkeleri için yer almaktadır. Buna göre 2017 yılında evli ve iki çocuklu için işverene maliyetin vergi yükü en yüksek olan ülkelerin sırasıyla Fransa, Yunanistan, İtalya, Finlandiya ve Belçika olduğu görülmektedir. Türkiye' de bu oran 2017 y1lı için \%37'dir. Yeni Zelanda' da bu oran 2017 yılında \%6,4 olarak gerçekleşmiş olup seçili ülkeler arasındaki en düşük orandır. Ortalama ücret alan bekâr çalışan için işveren maliyetinin vergi yükü oranı en yüksek olan ülkeler ise sırasıyla Belçika, Almanya, İtalya, Fransa ve Avusturya'dır. Türkiye' de bu oran 2017 yılı için \%38,7 olarak gerçekleşmiştir. Ortalama ücret alan bekâr çalışan için işveren maliyetinin vergi yükü oranı en düşük olan ülkenin \%7 ile Şili olduğu görülmektedir. 
Tablo 16. OECD Ülkelerinde Kurumlar Vergisi Oranları ile Kar Dağıtımında Toplam Vergi Yükü (2018)

\begin{tabular}{|c|c|c|}
\hline Ülkeler & Kurumlar Vergisi Oranı (\%) & Kar Dağıtımında Toplam Vergi Yükü (\%) \\
\hline Fransa & 34,4 & 54,1 \\
\hline Danimarka & 22,0 & 54,8 \\
\hline Belçika & 29,6 & 50,7 \\
\hline İsveç & 22,0 & 45,4 \\
\hline Finlandiya & 20,0 & 43,1 \\
\hline İtalya & 27,8 & 43,8 \\
\hline Avusturya & 25,0 & 45,6 \\
\hline Yunanistan & 29,0 & 39,7 \\
\hline Hollanda & 25,0 & 43,8 \\
\hline Lüksemburg & 26,0 & 41,5 \\
\hline Norveç & 23,0 & 46,6 \\
\hline Macaristan & 9,0 & 22,7 \\
\hline İzlanda & 20,0 & 37,6 \\
\hline Almanya & 29,8 & 48,3 \\
\hline Slovenya & 19,0 & 39,3 \\
\hline Çek Cumhuriyeti & 19,0 & 31,2 \\
\hline Portekiz & 31,5 & 50,7 \\
\hline Polonya & 19,0 & 34,4 \\
\hline İspanya & 25,0 & 42,3 \\
\hline İngiltere & 19,0 & 49,9 \\
\hline Estonya & 20,0 & 20,0 \\
\hline Slovakya & 21,0 & 26,5 \\
\hline İsrail & 23,0 & 48,4 \\
\hline Kanada & 26,8 & 55,6 \\
\hline Yeni Zelanda & 28,0 & 33,0 \\
\hline Japonya & 29,7 & 44,0 \\
\hline Letonya & 20,0 & 20,0 \\
\hline İsviçre & 21,1 & 37,8 \\
\hline Avustralya & 30,0 & 47,0 \\
\hline $\mathrm{ABD}$ & 25,8 & 47,5 \\
\hline Kore & 27,5 & 56,7 \\
\hline Türkiye & 22,0 & 35,0 \\
\hline İrlanda & 12,5 & 57,1 \\
\hline Şili & 25,0 & 35,0 \\
\hline Meksika & 30,0 & 42,0 \\
\hline
\end{tabular}

Tablo 16’da 2018 yılı için OECD ülkelerinde kurumlar vergisi oranları ile kar dağıtımında toplam vergi yükü oranları yer almaktadır. 2018 yılında kurumlar vergisi oranı en yüksek olan OECD ülkelerinin sırasıyla Fransa, Portekiz, Avustralya, Meksika ve Almanya olduğu, kurumlar vergisi oranı en düşük olan OECD ülkelerinin ise sırasıyla Macaristan, İrlanda, Slovenya, Polonya ve İngiltere olduğu görülmektedir. Türkiye'de bu oran \%22'dir. OECD ülkeleri 2018 y1lı için kar dağıtımında toplam vergi yükü oranları açısından değerlendirildiğinde bu oranın en yüksek olduğu OECD ülkelerinin sırasıyla İrlanda, Kore, Kanada, Danimarka ve Fransa olduğu, kar dağıtımında toplam vergi yükü en düşük olan OECD ülkelerinin ise Estonya, Letonya, Macaristan, Slovakya ve Çek Cumhuriyeti olduğu gözlenmektedir. Türkiye'de bu oran \%35 düzeyindedir.

\section{Vergiler ve Vergi Yükünün Ekonomik Etkileri}

Vergiler, bir ülke ekonomisinde mevcut olan mal ve hizmetlerin üretim düzeyini, üretim faktörlerinin gelir ve fiyatlarını dolaylı veya dolaysız bir biçimde etkilemektedir (Abdiyeva ve Baygonuşova, 2016: 59). Dolayısıyla, vergiler ülkeler açısından bütçe dengesini sağlamada, sermaye birikimiyle yatırım seviyesini yükseltmede önemli bir rol oynamaktadır. Gelişmekte olan ülkelerde vergi kavramı, ekonomik kalkınmanın ve refahın sağlanmasında, tasarruf seviyesinin tespit edilmesinde ve optimal kaynak dağılımında önem kazanmaktadır (Yardımcıoğlu, 2012: 27-28).

Vergiler, bir ülkede yer alan bütün kesimlerin ekonomik, sosyo-politik faaliyetlerinin merkezindedir. Hızlı ve sürdürülebilir ekonomik büyümenin ve bölgesel eşitsizliklerin sona erdirilmesinde ülkede yürürlükte bulunan vergi sisteminin niteliği ve etkisi çok fazladır (Gökbunar, 1998: 1). Vergiler, ekonomik büyüme üzerinde iki temel fonksiyona sahiptir. Bunlardan birincisi, özel tüketimlerdeki yükselişi engelleyip kaynakların yatırımlara yönlendirilmesini sağlayarak 
yatırım seviyesini yükseltmektir. Dolayısıyla vergiler, ekonomik karar birimlerinin gelecekteki yatırımlarını yükseltmek amacıyla bugünkü tüketim düzeylerini azaltmalarına yol açmaktadır. Vergilerin ekonomik büyüme üzerindeki ikinci fonksiyonu, özel ekonomi kaynaklı gelirlerin kamu ekonomisine aktarımını gerçekleştirmek ve bu şekilde belirlenen makroekonomik amaçlara ulaşmak için bir kaynak yaratmaktır.

Vergilerin farklı birçok makroekonomik gösterge üzerinde etkili olması çerçevesinde vergi yükü ve ekonomik büyüme ilişkisi önem kazanmaktadır. Hükümetlerin uygulamış oldukları vergi miktarının bir sınırı olup bu sınır aşıldığında vergi kaynakları azalmakta, vergi kaçakçılığı artmakta ve ekonominin faaliyet hacmi yavaşlamaktadır (Türk, 1999; Tekbaş ve Dökmen, 2007: 196). Dolayısıyla vergi yükünün ekonomik faaliyet hacmini kötüleştirmemesi gerekmektedir. Vergi yükü, ödenen vergiyle vergi ödeme gücünün bir fonksiyonu olması nedeniyle vergi politikalarına ilişkin düzenlemelerin kabul edilmesinde, bu düzenlemelere karşı tepki meydana gelmesinde ve vergi direncinin baş göstermesinde aktif bir rol üstlenmektedir (Tekbaş ve Dökmen, 2007: 197).

Vergi yoluyla bireylerin gelirlerinde azalma oluştuğundan bireyler için vergi olgusu bir yük olarak görülmektedir. Vergi toplumsal bakımdan da bir yük niteliğindedir. Vergi ödeyen bireylerin yaşadığı gelir kaybı, kamusal harcamalardan yararlanan bireylerin gelir artışlarından daha düşük seviyede ise vergi yükündeki yükselişin ekonomiye olumlu katkıda bulunduğu söylenebilecektir. Bireylerin satın alma güçlerinde meydana gelen azalma sonucunda tüketim ve tasarruf kararlarını değiştirmek istemeleri zamanla toplumun tüm kesimine yayılarak toplumsal bir olguya dönüşecektir (Kalenderoğlu, 2006: 118). Dolayısıyla, vergi yükünde oluşacak yükselmenin, ücreti de doğrudan etkilediği düşünüldüğünde, vergi yükü emek arzını da etkileyecektir. Bireylerin reel gelir seviyelerine göre çalışma ya da boş zaman tercihinde bulunduğu dikkate alındığında, vergiler bireylerin çalışma isteği ile işgücü arzı üzerinde etkili olacaktır. Çalışmamayı daha cazip yapacak bir vergi sistemi işgücü arzının azalmasına yol açacaktır (Burtless ve Hausman, 1978: 1105-1108; Hausman, 1985: 215-220; Turhan, 1998: 329-331; Şener, 2006: 243-244). Bu durumun tersi olarak bireylerin ödemiş oldukları vergiler dolayısıyla üstlenmiş oldukları mali sorumluluğu çalışarak karşılayabilmeleri durumunda işgücü arzı artacaktır. Dolaylı vergilere ağırlık verilerek kamu harcamalarının karşılanması halinde de benzer sonuçlar doğabilecektir (Musgrave ve Musgrave, 1973: 467-468; Bulutoğlu, 1971: 303-305; Blomquist ve Hansson-Brusewitz, 1990: 318-319; MaCurdy ve diğerleri, 1990: 416-418). Sonuç olarak vasıtalı vergiler dolayısıyla yükselen hayat pahalılığ1 ve satın alma gücündeki azalma, bireyleri daha çok çalışmaya itebilecektir.

Vergiler işgücü arzının yanı sıra sermaye birikimi üzerinde de etkili olduğundan sermaye birikimi yaratacak olan alanlara yatırım yapılması konusunda önem kazanmaktadır. Vergilerle elde edilen kaynakların doğru, etkin ve verimli alanlarda kullanılması ile vergi yapısının yoksulluk ve gelir dağılımını iyileştirici yönde olması durumunda ekonomik büyüme, kalkınma ve refah seviyesi de artacaktır.

\section{Sonuç ve Değerlendirme}

Türkiye ekonomisinde son yıllarda kamuoyunda en fazla gündemde olan konuların başında devlet tarafından toplanan vergiler gelmektedir. Yükselen döviz kuru, faiz, enflasyon ve işsizlik oranları gibi temel makroekonomik göstergelere bağlı olarak devlet uygulamış olduğu vergi politikalarıyla vergi gelirini de yıllar içerisinde artırmıştır. Vergi gelirlerinin yıllar içerisinde hızla artması sonucunda vergi yükü de artmıştır. Vergi yükü az gelişmiş ve gelişmekte olan ülkelerde gelir dağılımı adaletini sağlamada ve tasarruf-yatırım düzeylerini etkileme hususunda oldukça önemli bir rol üstlendiğinden ekonomik büyümenin meydana gelmesinde büyük önem taşımaktadır.

Çalışmada OECD ülkeleri ve seçilmiş ülkelerle yapılan vergi yükü karşılaştırması Türkiye'nin düşük vergi yüküne sahip bir ekonomi olduğunu, bu vergi yükünün ağırlıklı olarak dolaylı vergilerden meydana geldiğini ve dolayısıyla vergi ve gelir dağılımı adaletini sağlamada yetersiz bir vergi yapısına sahip olduğunu göstermektedir. OECD ülkelerinde bireylerin vergilerden sonra sahip oldukları gelirlerinin alım gücü Türkiye'deki vergilerden sonra bireylerin ellerinde kalan 
gelirin alım gücünden daha fazladır. Türkiye' de mevcut olan kayıt dışı ekonomi şartları da dikkate alındığında vergi yükünün ekonomi üzerindeki etkileri daha net bir biçimde görülmektedir.

Türkiye' de artan kamu harcamalarının karşılanmasında temel kaynak olarak kabul edilen vergilerin, ekonomik ve sosyal amaçları etkin bir biçimde yerine getirmesi gerekmektedir. Vergi yükünün ağırlığı ve bu ağırlığın toplumdaki farklı gelir grupları arasında adil dağıtımının sağlanamaması, kayıt dışı faaliyetlere yönelen kesimin büyüklüğü, vergi bilincinin zayıf olması gibi faktörler vergi yükünün adil dağılımını engelleyerek ekonomik istikrardan uzaklaşmaya neden olmaktadır. Bu şartlar altında verginin sosyal fonksiyonunu yerine getirdiğini ifade etmek mümkün değildir.

Türkiye' de dolaysız vergilerin toplam vergi gelirleri içindeki payı oldukça düşük düzeydedir. Başta özel tüketim vergisi (ÖTV) olmak üzere, özel iletişim ve özel işlem vergilerinin her geçen gün vergi hasılatından daha büyük oranda pay aldıkları görülmektedir. Bu durum vergilendirmede adalet ilkesine aykırılık teşkil etmektedir. Gelir vergisinde vergi adaletini olumsuz yönde etkileyen en önemli sorun bu verginin beyana dayalı olmaktan çıkıp, fiilen kaynakta kesinti yoluyla alınan bir vergi şekline dönüşmesidir. Kaynakta kesinti şeklinde toplanan verginin önemli bir kısmı çalışanların ücret gelirlerinden elde edilmektedir.

Sonuç olarak; Türkiye'de dolaylı vergiler her geçen gün artan bir biçimde uygulama alanı bulmakta, toplam vergi yükünün çok büyük bir kısmı nihai mal ve hizmet talep eden bireylerin üzerinde yoğunlaşmakta, gelir dağılımı bozulmakta, ekonomik büyüme olumsuz yönde etkilenmektedir. Dolayısıyla Türkiye'de vergi sistemi ciddi bir vergi reformuna ihtiyaç duymaktadır. Siyasi tercih ve yönlendirmelerden etkilenmeyen, toplumsal yapıya uygun vergi politikası belirlenerek uygulanmalıdır. Vergi yükünün bireyler arasındaki dağılımını adil kılan, verginin tabana yayılmasını sağlayan, dolaylı vergiler üzerindeki baskıyı azaltan vergi politikalarıyla birlikte kayıt dışı ekonominin tam olarak vergilendirilmesi ve vergi kaçakçılığının engellenmesiyle sürdürülebilir ekonomik büyüme gerçekleşecektir.

\section{Kaynakça}

Abdiyeva, R. \& Baygonuşova, D. (2016). Geçiş ekonomilerinde vergi gelirleri ve ekonomik büyüme ilişkisi: Kırgızistan örneği. Akademik Bakış Dergisi, (53), 59-71.

Akalın, G. (2001). Türkiye'de piyasa ekonomisine geçiş süreci ve ekonomik kriz, TíSK.

Anastassiou, T. \& Dritsaki, C. (2005). Tax revenues and economic growth: An empirical investigation for greece using causality analysis. Journal of Social Sciences, 1(2), 99-104.

Ardıç, O., Erus, B. \& Soydan, G. (2010). An evaluation of indirect taxes in Turkey. Economics Bulletin, 30(4), 2787-2801.

Arısoy, İ. \& Ünlükaplan, İ. (2010). Tax composition and growth in Turkey: an empirical analysis. International Research Journal of Finance and Economics, 59, 50-61.

Arnold, J. (2008). Do tax structures affect aggregate economic growth? Empirical evidence from a panel of OECD countries. Economics Department Working Papers, 643, OECD.

Ay, H. \& Haydanlı, M. L. (2017). Vergi Yükü Ekseninde Toplumsal Yapının Gelir Dağılımı ve Yoksullukla İlişkisi. Adnan Menderes Üniversitesi Sosyal Bilimler Enstitüsü Dergisi, 4(3), 136-153.

Blomquist, N.S. \& Hansson-Brusewitz, U. (1990). The effect of taxes on male and female labor supply in sweden. Journal of Human Resources, 317-357.

Boğa, S. (2020). Türkiye' de vergi gelirleri ve ekonomik büyüme arasındaki asimetrik ilişki: NARDL eş bütünleşme yaklaşımı. Üçüncü Sektör Sosyal Ekonomi Dergisi, 55(1), 487-507.

Bulutoğlu, K. (1971). Kamu ekonomisine giriş, 4. Bask1, Sermet Matbaası, İstanbul.

Burtless, G. \& Hausman, J.A. (1978). The effect of taxation on labor supply: Evaluating the gary negative income tax experiment, Journal of Political Economy, 86(6), 1103-1130.

Canavire-Bacarreza, G., Martinez-Vazquez, J. \& Vulovic, V. (2013). Taxation and economic growth in Latin America. IDB Working Paper Series, 431, Inter-American Development Bank.

Çelikay, F. (2018). Vergi yükünün ekonomik büyüme hızı üzerindeki etkileri: Türkiye'deki iller örnekleminde ampirik bir analiz (2005-2014). İktisadi İdari ve Siyasal Araştırmalar Dergisi, 3(5), 37 55. 
Demir, İ.C. (2013). Türkiye'de vergi yükü (objektif ve subjektif yönleriyle), Dora Yayınları. Bursa.

De Wet, A.H., Schoeman, N.J. \& Koch, S.F. (2005). The South African tax mix and economic growth. South African Journal of Economic and Management Sciences, 8(2), 201-210.

Easterly, W. \& Rebelo, S. (1993). Fiscal policy and economic growth: an empirical investigation. NBER Working Paper, 4499, Cambridge, Mass.

Edizdoğan N., Çetinkaya Ö. \& Gümüş E. (2013). Kamu maliyesi, Bursa.

Engen, S. \& Skinner, J. (1992). Fiscal policy and economic growth, NBER Working Paper, 4223, National Bureau of Economic Research, Cambridge, Mass.

Erdoğan, E., Topcu, M. \& Bahar, O. (2013). Vergi gelirleri ve ekonomik büyüme ilişkisi: Türkiye ekonomisi üzerine eş bütünleşme ve nedensellik analizi", Finans Politik $\mathcal{E}$ Ekonomik Yorumlar, 50(576), 99-109.

Gelir İdaresi Başkanlığı (2020). Çeşitli Vergi İstatistikleri, https://gib.gov.tr/sites/default/files/fileadmin/user_upload/VI/CVI/Tablo_74.xls.htm, (07.04.2021).

Giray, F. (2005). Küreselleşme sürecinde vergi rekabeti ve boyutlar. Akdeniz İİBF Dergisi, 9, 93-122.

Göçer, İ., Mercan, M., Bulut, Ş. \& Dam, M.M. (2010). Ekonomik büyüme ile vergi gelirleri arasındaki ilişki: sınır testi yaklaşımı. Dumlupınar Üniversitesi Sosyal Bilimler Enstitüsü Dergisi, 28, 97-110.

Gökbunar, A. R. (1998). Vergileme ilkeleri ve küreselleşme. Celal Bayar Üniversitesi İİF Yönetim ve Ekonomi Dergisi, 177-201.

Hausman, J.A. (1985). Taxes and labor supply. Handbook of Public Economics, 1, 213-263.

İnaltong, C. (2012). Vergi yükü: Türkiye ve OECD ülkeleri karşılaştırması. Vergi Dünyası, 369, 16-30.

Kalenderoğlu, M. (2006). Kamu maliyesi bütçe ve borçlanma, V. Baskı, Ankara.

Karayılmazlar, E. \& Göde, B. (2017). Vergi yükünün ekonomik büyüme üzerine etkisi. Ömer Halisdemir Üniversitesi, İktisadi ve İdari Bilimler Fakültesi Dergisi, 10(4), 131-142.

Katırcıoğlu, S.T. (2010). Is there a long-run relationship between taxation and growth: the case of Turkey. Romanian Journal of Economic Forecasting, 13(1), 99-106.

Kılıçaslan, H. \& Yavan, S. (2017). Türkiye'de vergi yükünün değerlendirilmesi: OECD ülkeleri ile karşılaştırma. Ekonomik ve Sosyal Araştırmalar Dergisi, 13(2), 33-51.

Koch, S.F., Schoeman, N.J. \& Van Tonder, J.J. (2005). Economic growth and the structure of taxes in South Africa: 1960-2002. South African Journal of Economics, 73(2), 190-210.

Koç, Ö. E. (2019). Türkiye' de vergi yükü ve ekonomik büyüme ilişkisi. Alanya Akademik Bakış, 3(3), 247-259.

Korkmaz, A. (2001). Türkiye'de asgari ücretin mali yönü, Cumhuriyet Üniversitesi İktisadi ve İdari Bilimler Fakültesi Dergisi, 2(1), 275-285.

Korkmaz, A. (2004). Bir sosyal politika aracı olarak Türkiye'de asgari ücret: 1951-2003. Kocaeli Üniversitesi Sosyal Bilimler Enstitüsü Dergisi, 7, 53-71.

Kutbay, H. (2021). Vergi yükünün ve yapısının ekonomik büyüme üzerindeki etkileri: OECD ülkeleri için panel veri analizi. Mali Çözüm Dergisi, 31(164), 13-35.

Lee, Y. \& Gordon, R.H. (2005). Tax structure and economic growth. Journal of Public Economics, 89, 1027-1043.

Macurdy, T., Green, D. \& Paarsch, H. (1990). Assessing empirical approaches for analyzing taxes and labor supply. Journal of Human Resources, 25(3), 415-490.

Mangır, F. \& Ertuğrul, H.M. (2012). Vergi yükü ve ekonomik büyüme ilişkisi: 1988-2011 Türkiye örneği. Maliye Dergisi, 162, 256-265.

Marsden, K. (1984). Links between taxes and economic growth some empirical evidence. World Bank Staff Working Papers, 605, Washington DC.

Mucuk, M. \& Alptekin, V. (2008). Türkiye' de vergi gelirleri ve ekonomik büyüme ilişkisi: VAR analizi (1975-2006). Maliye Dergisi, 155, 159-174.

Musgrave, R.A. \& Musgrave, P.B. (1973). Public finance in theory and practice. International Student Edition, McGraw-Hill, Tokyo. 
http://www.oecd.org/document/60/0,3746,en_2649_37427_1942460_1_1_1_37427,00.html\#A

_RevenueStatistics, (05.04.2021).

Organ, İ., \& Ergen, E. (2017). Türkiye' de vergi yükünün ekonomik büyümeye etkileri üzerine bir çalışma. Pamukkale Üniversitesi Sosyal Bilimler Enstitüsü Dergisi, (27). 197-207.

Öz, E. \& Yaraşır, S. (2009). Global bir kavram: vergi rekabeti. İstanbul Üniversitesi İktisat Fakültesi Maliye Araştırma Merkezi Konferansları, 52. Seri, Prof. Dr. Şerafettin Aksoy'a Armağan, 1-40, http://istanbul.dergipark.gov.tr/download/article-file/7234, (04.04.2021).

Özpençe, Ö.\& Mercan, N. (2020). The relationship between tax burden and economic growth: Turkey case. Journal of Business, Economics and Finance, 9(2), 143-154.

Padda, I.U.H. \& Akram, N. (2009). The impact of tax policies on economic growth: evidence from South-Asian economies. The Pakistan Development Review, 48(4), 961-971.

Pesaran, M. H.,Shin, Y. \& Smith, R., J. (2001). Bounds testing aproaches to the analysis of level relationships. Journal of Applied Econometrics, 16, 289-326.

Saraç, T.B. (2015). Vergi yükü ve ekonomik büyüme ilişkisi: Türkiye örneği. Maliye Dergisi, 169, 2135.

Susam, N. \& Oktayer, N. (2007). Türkiye ekonomisinde genel bütçe vergi gelirleri içinde dolaysız ve dolaylı vergiler (1995-2005). Atatürk Üniversitesi İktisadi ve İdari Bilimler Dergisi, 21(2), 105-123.

Şener, O. (2006). Kamu ekonomisi: teori ve uygulama, 8. Baskı, Beta Yayınc1lık, Bursa.

T.C. Cumhurbaşkanlığ1 Strateji ve Bütçe Başkanlığı (2020). Ekonomik ve Sosyal Göstergeler, https:/ / www.sbb.gov.tr/ekonomik-ve-sosyal-gostergeler/\#1540022217017-46a9b2d0-b50a, (06.04.2021).

Tekbaş, A. \& Dökmen, G. (2007). Türkiye' de vergi yükünün bölgesel dağılımı, Maliye Dergisi, 153, 196-213.

Temiz, D. (2008). Türkiye' de vergi gelirleri ve ekonomik büyüme ilişkisi: 1960-2006 dönemi. 2. Ulusal İktisat Kongresi, 20-22 Şubat, İzmir.

Tosun, M.S. \& Abizadeh, S. (2005). Economic growth and tax components: an analysis of tax changes in OECD. Applied Economics, 37, 2251-2263.

Turhan, S. (1998). Vergi teorisi ve politikası, 6. Bask1, Filiz Kitabevi, İstanbul.

TÜIK (2020). Gelir, Yaşam, Tüketim ve Yoksulluk Araştırması, https:// data.tuik.gov.tr/Kategori/GetKategori?p=gelir-yasam-tuketim-ve-yoksulluk$107 \&$ dil=1, (05.04.2021).

Türk, İ. (1999). Kamu maliyesi, Turhan Kitabevi, Ankara.

TÜSİAD (2012). Dolaylı ve dolaysız vergilerin Türk mali sistemi içerisindeki yeri: siyasal, sosyal ve ekonomik sonuçları, https:/ / tusiad.org, (01.04.2021).

Veronika, B. \& Lenka, J. (2012). Taxation of corporations and their impact on economic growth: the case of EU countries. Journal of Competitiveness, 4(4), 96-108.

Yardımcıoğlu, F. (2012). OECD ülkelerinde sağlık ve ekonomik büyüme ilişkisinin ekonometrik bir incelemesi. Eskişehir Osmangazi Üniversitesi Sosyal Bilimler Dergisi, 13(2), 27-47.

Yeşilyurt, H. (2016). Bazı açılardan Türk vergi sistemi eleştirisi: kirli yaşıyoruz, temizmiş gibi yapıyoruz. Türkiye Barolar Birliği Dergisi, 29(122), 235-258.

Widmalm, F. (2001). Tax structure and growth: are some taxes better than others?. Public Choice, 107(3/4), 199-219.

\section{Aim and Scope}

\section{Extended Abstract}

The two most important factors determining the saving and expenditure decisions of both institutions and individuals are income and tax rates. The concept of the tax burden is one of the development indicators of a country and is also crucial in terms of indicating the share of the public economy in the national economy. Due to the negative impacts of the tax burden on disposable income, the savings rate decreases, and the functioning of economic activities suffers. Therefore, the tax system implemented in a country should be suitable for the taxpayer's ability to pay. 
The aim of the research study comprises of determining the total tax burden in the world and Turkey, comparing the total tax burden existing in Turkey with of the OECD countries as well as selected countries, evaluating the effects of taxes and the tax burden on economic growth.

\section{Methods}

In this study, the official statistical data obtained from the OECD, the Presidency of Strategy and Budget, TSI, and the Presidency of the Revenue Administration are utilized to reveal the characteristics and levels of the tax burden in Turkey and other countries around the world, and to compare the tax burden in Turkey with the overall tax burden in the world as well as the OECD countries. The structure of the tax system, as well as the direct and indirect tax rates in Turkey throughout the period 2002-2020, are emphasized. At the same time, the literature review regarding the effects of taxes and tax burden on economic growth is made, and the economic effects of tax burden are also mentioned.

\section{Findings}

Depending on the main macroeconomic indicators such as the exchange rates, interest rates, inflation rates, and unemployment rates which have been increasing in Turkey over the period 20022020, the State has aggravated its tax revenues along with the tax policies that have been implemented over the years.

As a result of the rapid increase in tax revenues over the years, the tax burden has also increased. Upon comparing Turkey with the selected countries as well as the OECD countries in terms of the statistical data and economic indicators obtained in this study, it is found that Turkey's economy has a low tax burden, the tax burden mainly stems from indirect taxes and consequently, the country has an inadequate tax structure in ensuring fair tax and income distributions.

\section{Conclusion}

Indirect taxes gradually attain application domains in Turkey, a large portion of the total tax burden devolves on individuals who demand final goods and services. Since indirect taxes are based on spending rather than earning incomes, they are mostly imposed on the incomes of individuals who consume more instead of earning more. In this context, it leads to an unfair result since it causes more taxes to be collected from the segment with relatively lower income levels. Nonetheless, direct taxes have a fairer structure as they are imposed on the basis of tax payment according to the level of tax awareness or tax ethics the taxpayers have, rather than their income or capital. Upon considering the existing conditions in the informal economy in Turkey, the impact of the tax burden on the economy is apparently lighter. In this context, the tax system in Turkey requires serious tax reform. Sustainable economic growth would be achieved through full taxation of the informal economy and prevention of tax evasion, along with tax policies that maintain a fair distribution of the tax burden fair among individuals, ensure the dispersion of the tax on the base and reduce the pressure on indirect taxes. 